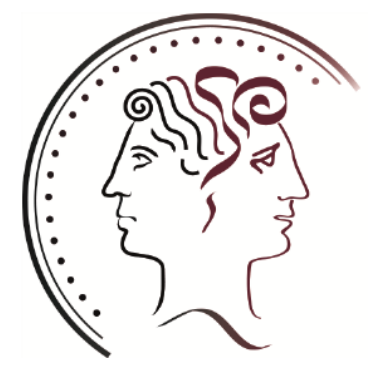

Working Papers of the Priority Programme 1859

Experience and Expectation.

Historical Foundations of Economic Behaviour

Edited by Alexander Nützenadel und Jochen Streb

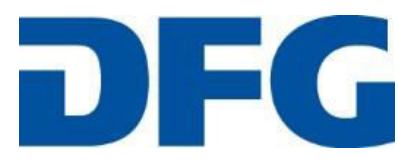

No 25 (2020, October)

Papadia, Andrea / Schioppa, Claudio A.

Foreign Debt, Capital Controls, and Secondary Markets: Theory and Evidence from Nazi Germany 
Arbeitspapiere des Schwerpunktprogramms 1859 der Deutschen Forschungsgemeinschaft „Erfahrung und Erwartung. Historische Grundlagen ökonomischen Handelns“ /

Working Papers of the German Research Foundation's Priority Programme 1859

"Experience and Expectation. Historical Foundations of Economic Behaviour"

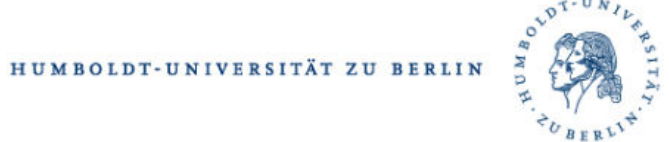

Published in co-operation with the documentation and publication service of the Humboldt University, Berlin (https://edoc.hu-berlin.de).

ISSN: 2510-053X

Redaktion: Alexander Nützenadel, Jochen Streb, Ingo Köhler

V.i.S.d.P.: Alexander Nützenadel, Jochen Streb

SPP 1859 "Erfahrung und Erwartung. Historische Grundlagen ökonomischen Handelns"

Sitz der Geschäftsführung:

Humboldt-Universität

Friedrichstr. 191-193, 10117 Berlin

Tel: 0049-30-2093-70615, Fax: 0049-30-2093-70644

Web: https://www.experience-expectation.de

Koordinatoren: Alexander Nützenadel, Jochen Streb

Assistent der Koordinatoren: Ingo Köhler

Recommended citation:

Papadia, Andrea / Schioppa, Claudio A. (2020): Foreign Debt, Capital Controls, and Secondary Markets:

Theory and Evidence from Nazi Germany. Working Papers of the Priority Programme 1859 "Experience and Expectation. Historical Foundations of Economic Behaviour" No 25 (October), Berlin

(C) 2020 DFG-Schwerpunktprogramm 1859 „Erfahrung und Erwartung. Historische Grundlagen ökonomischen Handelns"

The opinions and conclusions set forth in the Working Papers of the Priority Programme 1859 Experience and Expectation. Historical Foundations of Economic Behaviour are those of the authors. Reprints and any other use for publication that goes beyond the usual quotations and references in academic research and teaching require the explicit approval of the editors and must state the authors and original source. 


\title{
Foreign Debt, Capital Controls, and Secondary Markets: Theory and Evidence from Nazi Germany*
}

\author{
Andrea Papadia ${ }^{\dagger}$ \\ Claudio A. Schioppa ${ }^{\ddagger}$ \\ University of Bonn \\ Université libre de Bruxelles
}

September 10, 2020

\begin{abstract}
We show how elite capture affects optimal debt repatriations and management of official reserves under capital controls, bridging literature on debt buybacks and secondary markets. The model we provide guides our study of one of history's largest debt repatriations -in 1930s Germany. Authorities kept private repatriations under strict control -avoiding detrimental macroeconomic effects- while allowing discretionary repatriations so to reap internal political benefits. German assets exhibited large spreads between their domestic and foreign prices, granting arbitrage profits to those who had forex access. New data reveals that spread dynamics were affected by the impact of capital controls on secondary markets.
\end{abstract}

JEL: E65, F38, H63, N24

Keywords: Sovereign risk, Capital controls, Elite capture, Germany, Nazi regime, Foreign debt, Secondary markets

*For their comments and suggestions, we thank Ramon Marimon, Josefin Meyer, Kim Oosterlinck, Albrecht Ritschl, Moritz Schularick, Christoph Trebesch, Philippe Weil, and participants at the EHES Conference in London, EHA Annual Meeting in Washington DC, 2016 RES Conference, as well as seminar and workshop participants at the EUI, Warwick University, Queen's University Belfast, and LSE. We thank William O. Brown and Richard C. K. Burdekin for sharing their data with us, and Ben White and Lorna Williams at the Bank of England Archive and the staff of the LSE Library for their patience and help. Andrea Papadia gratefully acknowledges financial support during the various stages of writing this paper from the MacroFinance Lab at the University of Bonn, the Pierre Werner Chair of the Robert Schuman Centre for Advanced Studies and the Max Weber Program at the EUI, the LSE and the Economic History Society. Claudio Schioppa thanks Pierluigi Ciocca and acknowledges research grants from Fondazione Luigi Einaudi. All errors are our own.

${ }^{\dagger}$ Department of Economics, Germany. Contact: Papadia@uni-bonn.de

${ }^{\ddagger}$ SBS-EM, ECARES, Belgium. Contact: Claudio.Schioppa@ulb.be 
The Protestant Ethic...

[...] the Schachtian policy of buying back un-serviced loans below par contributed to crushing Germany's moral standing with the creditors.

Hermann Abs, Head of the German

Delegation at the 1952 London Conference on German External Debts ${ }^{1}$ ...and the Spirit of Capitalism.

He [Hermann Abs] bought back some of the external German debt [...] and made a large arbitrage profit (the difference between the very low price of German debt abroad, and its face value price within Germany) on the deal on his own account. ${ }^{2}$

\section{Introduction}

Capital controls are ubiquitous. According to the database of Fernández, Klein, Rebucci, Schindler, and Uribe (2016), in 2017 only 8 countries out of the 100 analyzed had no capital controls of sorts and just 32 countries could be classified as having generally unimpeded (open) capital flows. ${ }^{3}$ When in place, controls on capital flows range from simple provisions to avoid excessive risk-taking in some business sectors (e.g. pension funds and insurance) to complete government control over all capital inflows and outflows. In general, capital controls take the form of one or more of the following (partially overlapping) cases: a) a crisis tool e.g. to stop bank runs and capital flight (e.g. Greece from 2015 to 2019) or prevent large capital outflows that would endanger the stability of the exchange rate and debt sustainability (e.g. Iceland from 2008 to 2017); b) a macroprudential policy tool, e.g. in the form of control on inflows, aimed at achieving one or more of these policy objectives: reduce pressure on the exchange rate ${ }^{4}$, alter the composition of flows, reduce their volume, and allow for a more independent monetary policy ${ }^{5}$; c) a temporary tool (Klein, 2012; Reinhart and Smith, 2002), which can possibly evolve into a long-term policy, e.g. the exchange control systems established in the U.K. and other European countries during World War II that stayed in place well into the 1970s (Dooley, 1996); d) a defining and essential feature of an economic system, as in the cases of contemporary China or India.

\footnotetext{
${ }^{1}$ Klug (1993, page 54), originally from Schwarz (1982, page 60). The introduction of the policy in question actually precedes by a year Hjalmar Schacht's return to the Reichsbank.

${ }^{2}$ James (2004, page 59). In the 1930s, when these transactions took place, Abs was a director at Deutsche Bank. After World War II he would become a most important figure in German and world financial circles. David Rockefeller dubbed him "the leading banker of the world" (West Germany: Two Sprecher for One, Time magazine, June 16, 1967).

${ }^{3}$ According to the most recent version of their database (June 2019).

${ }^{4}$ New mercantilist policies of foreign reserve accumulation might complement this objective. For an overview on the prudential vs mercantilist motive for reserve accumulation see Costinot, Lorenzoni, and Werning (2014), Durdu, Mendoza, and Terrones (2009), Ghosh, Ostry, and Tsangarides (2017), Pasricha (2020).

${ }^{5}$ See Magud, Reinhart, and Rogoff (2018) for a literature review and further discussion on these policy objectives.
} 
When a significant degree of capital controls is imposed, business conditions and economic life at large tend to be severely affected by the laws, decrees, regulations, revisions, exceptions, permission requests, delays, higher transaction costs, increased regulatory uncertainty, etc. that characterize such systems. Against this backdrop of increased regulatory hurdles, micromanagement, and government control, discretionary administrative decisions acquire greater importance and elites close to the political power have the opportunity to exploit the situation to their favour. ${ }^{6}$ On this point, James (2020) highlights the intrinsic arbitrariness that follows the imposition of capital controls while Rajan and Zingales (1998) suggest that capital controls are indeed a fundamental component of "relationship-based capitalism". The economic impact of elite capture can be significant: for example Hinnerich and Pettersson-Lidbom (2014) show that differences of up to $60 \%$ in the provision of public welfare in Sweden in the early 20th century were the result of distinct governance systems differently vulnerable to elite capture. Moreover, relationship-based capitalism does not foster the emergence of quality institutions, which in turn engenders increased sovereign defaults and reduced capital flows (Reinhart and Rogoff, 2004; Alfaro, Kalemli-Ozcan, and Volosovych, 2007; Schularick and Steger, 2008; Bai and Wei, 2012).

Elite capture only scratches the surface of the social and political consequences of capital controls. As an example, historically it has been relatively common for capital controls to take the form of exchange controls (Ghosh and Qureshi, 2016), thus facilitating restrictions on the current as well as on the capital account. Such considerations led Friedrich Hayek to assert, with specific reference to the wide-ranging capital controls of the interwar period of the 20th century, that "[t]he extent of the control over all life that economic control confers is nowhere better illustrated than in the field of foreign exchanges." 7 Unsurprisingly, once such control over economic life is established, it is difficult to relinquish it. This was the case of Germany, for example, where "[t] he aim of exchange control [...] after the advent of the National Socialists was the furtherance of their economic and political power both abroad and at home" 8 : an exemplary and tragic transformation in the above classification from case a) to c), and finally d).

With these considerations in mind, we address the question of how internal distribution motives can interfere with the economic objectives of capital controls. We do this both theoretically and by showing that the large debt repatriations carried out in Germany in the 1930s, one of the largest episodes of its kind, are explained by elite favouritism under capital controls.

The model. Agents in our model have outstanding foreign-currency private debt with foreign creditors. The domestic government imposes capital controls on all outflows in order

\footnotetext{
${ }^{6}$ Elite capture is documented in countries both with and without capital controls, economically developed or developing. Two examples on opposite sides of the spectrum are Johnson and Mitton (2003) that find that during the 1998 capital outflows controls in Malaysia, firms with political connections enjoyed larger stock gains; Tahoun (2014) finds that members of the US congress own more stock of firms contributing to their campaigns, and that these firms are then awarded more governmental contracts but only until the member of congress finally divests in those firms before retirement.

${ }^{7}$ Hayek (1944, page 92).

${ }^{8}$ From Ellis (1940b), page 167. Italics added.
} 
to protect its foreign exchange reserves, thereby forcing (partial) default on its citizens by (partially) blocking direct repayments to foreigners. In this situation, foreign creditors are willing to sell their claims at less than face value and domestic debtors are willing to buy them if they believe that this debt, once repatriated, will be enforced between domestic agents (this assumption will be discussed below). When the repatriated debt is domestically serviced, in local currency, there exists a positive price of sale (in foreign currency) such that the operation leads to arbitrage profits for domestic agents: strict capital controls that greatly limit the availability of foreign currency for domestic agents will ensure this. However, the arbitrage operation can only work if the domestic agent has access to foreign currency, a resource strictly controlled by the government. The government allocates its scarce foreign currency reserves between a public good, that requires imports and equally benefits all citizens, and debt repatriations. Repatriations are only allowed for a group of government supporters (the elite), who can therefore privately profit from the operation. Higher repatriations, however, lead to two collective detrimental effects: first, lower public spending that affects everyone's welfare; second, more debt is serviced, as contracts of repatriated debt will be enforced between domestic bondholders.

The model builds on the observation that, on one hand, stringent capital controls allow for the emergence of different power structures within a country that we describe with a non-utilitarian social welfare function representing elite capture. On the other hand, the economic opportunities that the elite can potentially exploit due to capital controls might run counter to the economic objective that led to their institution in the first place. Indeed, we show that, when the social planner is utilitarian, no resources are ever devoted to repatriations, thus reproducing the seminal result of Bulow and Rogoff (1991) (henceforth $\mathrm{BR}$ ) that the optimal level of debt repatriations ${ }^{9}$ is zero. ${ }^{10}$ A non-utilitarian social planner, however, might assign positive amounts of foreign currency reserves for the elite to carry out debt repatriations, depending on various structural characteristics of the economy and the practical implementation of capital controls. Thus, in order to advantage the elite, the government exploits opportunities from capital controls to conduct what amounts to a transfer of resources from the non-elite to the elite, even if this advantages foreign creditors by means of additional repayments (from the sale of the repatriated debt and its effects on prices). In short, the government gains control over the relative size of the slices of the cake (the internal distribution), at the cost of reducing the size of the cake (some resources are transferred to foreigners).

\footnotetext{
${ }^{9}$ Throughout the paper we use the term repatriations rather than the related term buybacks, often used in the macro and corporate finance literature. In a debt buyback it is the issuer of debt, private or public, that repurchases its own debt. A debt repatriation occurs when a domestic agent buys a debt obligation held by a foreign agent but issued by another domestic agent. It is thus a more general and appropriate term than buyback for the phenomenon we study in this paper.

${ }^{10}$ Despite this, sovereign buybacks often resurface as policy options: apart from the South American debt crisis of the 1980s, which triggered much attention and, inter alia, Bulow and Rogoff's investigation, they re-emerged in the European debt crisis of the 2010s (Buying Back Greek Debt Rewarded Hedge Funds, N.Y. Times, December 24, 2012) and during the 2016 US Presidential election campaign (Donald Trump wants to buy back Treasury bonds on the cheap, The Economist, May 6, 2016), for example.
} 
Our framework generalizes BR's result over additional dimensions: it incorporates capital controls and the role of secondary markets as a source of default (instead of an inherited debt overhang); it takes into account the internal balance of political power, allowing for the emergence of the friction between the decentralized source of demand for debt to be repatriated - the elite - and the social planner, who instead has an incentive to default on foreigners; it considers repatriations of private debt, a more general problem than buybacks as the policymaker is not the issuer of debt. The role of secondary markets within a framework with private debt is also present in Broner, Martin, and Ventura (2010) (henceforth BMV) and our model therefore merges the main intuitions of BR and BMV.

Sovereign authority, capital controls, and private debt. Regardless of the type, stringency, practical implementation, and duration, capital controls share one feature: they are imposed by the sovereign on the rest of the economy. ${ }^{11}$ This is an unsurprising remark, the implications of which are however not generally taken into account in theoretical models of international debt (exceptions are Wright (2006), Broner, Martin, and Ventura (2010), and Broner, Erce, Martin, and Ventura (2014)). Consider, for instance, that a sovereign imposing strict capital controls on outflows could effectively force a default ${ }^{12}$ on payments owed by private domestic agents to foreign creditors, even in the case when domestic debtors are willing and able to pay. ${ }^{13}$ The possibility of such an occurrence is normally referred to as transfer risk and is empirically relevant for international capital markets (Claessens and Embrechts, 2003; Cetorelli and Goldberg, 2006). However, a blanket foreign payments moratorium hides the fact that there are really two distinct mechanisms at play. First, direct repayments from domestic debtors to foreign creditors are blocked. Second, a change of debt ownership from foreign to domestic investors is prevented.

To illustrate the first point practically, consider the example of a German corporation that in July 1932 issued the following announcement to its US bondholders, two weeks before 7 million dollars in gold bonds it had issued under New York law came to maturity:

The German Foreign Exchange Control having denied permission for the transfer out of Germany of sufficient funds to pay the above described Notes in cash at maturity, the undersigned [..] offers to repay [..] five percent of [..] principal in cash, and the balance by the issue of [..] six per cent Guaranteed Gold Notes, Due July 15, 1937[..] $]^{14}$

Shortly thereafter, all private German debtors were required to service their foreigncurrency debt in domestic currency (the Reichsmark) and to make the payments to the Konversionskasse, a governmental body (an offshoot of the Reichsbank, the German central

\footnotetext{
${ }^{11}$ We consider cases where the sovereign is able to impose the controls de facto and not only de jure.

${ }^{12}$ For the sake of argument, assume sudden and unexpected capital controls and no collateral or debtor foreign assets for the creditors to seize.

${ }^{13}$ A financial embargo imposed on a third country could have similar effects, as it disrupts trade and financial relations between the target country and the rest of the world.

${ }^{14}$ From Kuczynski (1933). Foreign bondholders never got the full amount of either the interest payments or the principal, not in 1937 nor later.
} 
bank at the time). To extract payments, foreign bondholders had to interact with the Konversionskasse instead of the original debt issuer.

This last aspect also highlights that, when the sovereign takes control of capital flows, private commercial debt can exhibit properties typical of sovereign debt, namely the difficulty in enforcing contracts. In the example above, to the foreign bondholder it did not matter whether the original issuer of the defaulted bond was a private company, a municipality, or the German government itself: the situation de jure had been clearly superseded by a de facto situation where the foreign bondholder had to deal with the German government as if it were holding sovereign debt. ${ }^{15}$ For this reason, we can study aspects of private debt defaults and repatriations within the familiar framework of sovereign defaults models.

We implicitly assume that sovereign-like debt is enforceable, though not necessarily in the same way as private debt under foreign law. This assumption is the direct punishment approach, which better captures the legal and institutional framework by summarizing the debtor-creditor relationship with the power to enforce contracts and extract repayments (refer to Panizza, Sturzenegger, and Zettelmeyer (2009) for a review of the literature on sovereign defaults and the different theoretical approaches). A pure reputation-based approach does not easily allow for this treatment of sovereign debt, in some cases explicitly assuming that it is unenforceable, as in Grossman and Van Huyck (1988) ${ }^{16}$. Buchheit, DeLong, Chabert, and Zettlemeyer (2019) highlight the importance of analyzing the institutional and legal framework in debt crises, also with respect to secondary markets, while Schumacher, Trebesch, and Enderlein (2018) show how legal recourse against sovereign defaults has become over time an increasingly powerful tool for creditors, perhaps replacing the need for supersanctions observed before the 1950s (Panizza, Sturzenegger, and Zettelmeyer, 2009). As an example of the applicability of the direct punishment approach in our empirical setting, consider the 1923 occupation of the Ruhr by France and Belgium in order to directly extract reparations after Germany failed to deliver various shipments of commodities pursuant to the reparation schedule of the Versailles Treaty.

The case study. Empirically, we revisit the large-scale debt repatriation episode that took place in Germany in the 1930s. Repatriations started as a private initiative in 1931, before capital controls were imposed, and at their peak in 1933, amounted to $2 \%$ of German GDP. In total, 33\% of all German long-term foreign debt was repatriated to Germany by private German investors (Klug, 1993).

The episode offers an ideal setting for our framework. First, the Nazi government's goal of autarky (Ritschl, 2012) implies that capital controls can be considered exogenous to our problem, i.e. the government did not set capital controls in order to allow gains from debt repatriations. Second, the scarcity of foreign exchange was significant: foreign reserves fell from around $62 \%$ of the monetary base in 1930 to $2.2 \%$ in 1934 and $1 \%$ in

\footnotetext{
${ }^{15}$ This consideration holds both in cases of strategic (voluntary) or involuntary default.

16 "Sovereign debts [..] are above the law", "[..]the power to abrogate commitments [is] the essential property of sovereignty", "[..] historical cases in which one sovereign [..] seized the assets of another [..] sovereign who is failing to service its debts involve infringement of sovereignty", from Grossman and Van Huyck (1988), page 1088. For a legal perspective on the issue of sovereign immunity refer to Weidemaier (2014).
} 
1938 (Ellis, 1940a). Alternative uses of foreign reserves to repatriations were not only the imports needed for Hitler's rearmament and full employment plans, but also the bilateral negotiations with creditor countries in which debt-servicing was traded for imports. This meant that there was no room for splurging foreign currency on repatriations. Third, because of the previous two points, Germany did not have its reputation on international financial markets at heart in any way. Moreover, the creditor front had broken up early on (Toniolo, 2005) and instead of punishing Germany for its default decision, creditor countries were competing with each other to offer favourable trade deals to Germany in order to extract some of the scarce foreign exchange left in the country. Fourth, despite the scarcity of foreign reserves, influential individuals and companies - as well as the Nazi Party itself - were allowed by German authorities to carry out debt repatriations for their own profit.

German capital control regulations were extremely complex. This led, in practice, to different ways of extracting economic gains from repatriations. The driving force behind all these operations, however, was the difference valuation of the debt between foreign and domestic investors. Since this could not be arbitraged away due to the exchange controls, it led to the large spread between German securities traded in Berlin and international financial centers depicted in Figure 1.

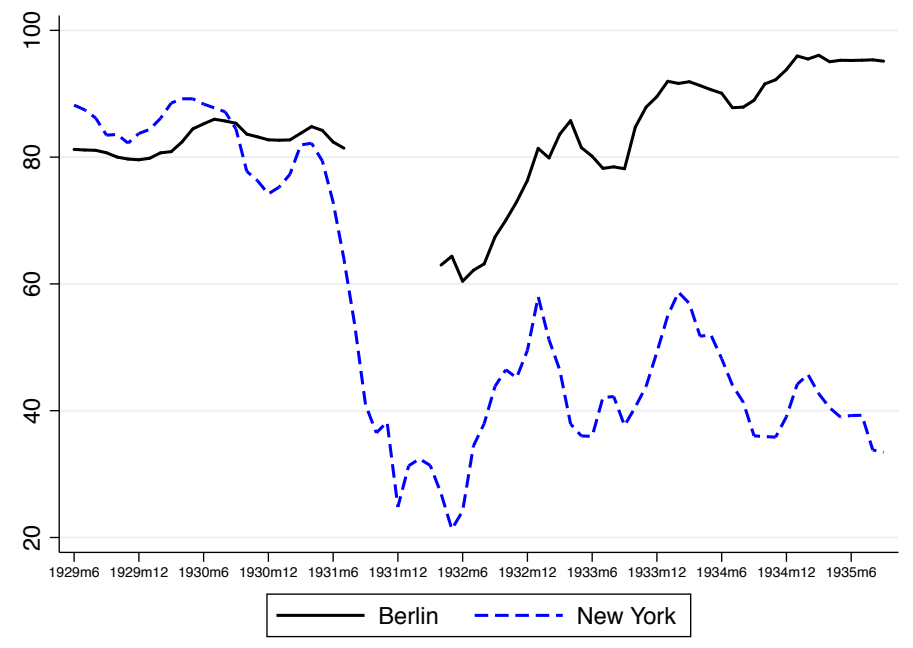

Figure 1: The index price of German 6\% Bonds in Berlin and New York.

Source: Institut für Konjunkturforschung (1933, 1936). Monthly frequency from January 1928 until October 1935. In 1931, the Berlin stock exchange was only open between the 1st of January and the 12th of July and from the 3rd to the 18th of August. Regular trading started again in April 1932. In March 1935, the coupon of the $6 \%$ bonds traded in Berlin was reduced to $4.5 \%$.

Differences in how exactly profits could be realized through repatriations existed, however, depending on whether the recipient of foreign exchange was a firm, a private investor, or an organization. The simplest instance was as follows: a private German investor would request foreign reserves from the Reichsbank and, if authorized, these funds would be earmarked for the specific operation of buying any one of the foreign currency-denominated German bonds trading at a discount in e.g. New York or London; once repatriated to Germany, these 
bonds would be often legally converted into securities in Reichsmarks. Converted or not, the debt issuer would service its debt in RM to a specifically designed institution, the previously mentioned Konversionskasse; the German creditor would get full payment (in RM) of interest and principal from the Konversionskasse and, from January 1934, the owner of the asset could sell it on the German market. Below, we also illustrate a more complex repatriation mechanics - Figure 13 in appendix C.2 provides a visual representation of the scheme - but the economic consequences of different repatriation modes were essentially identical to the basic typology just presented here.

We rationalize the behavior of the German authorities as a way to reward supporters and allies, which we characterize as the elite, in line with James (2020). Unfortunately, complete records of individual repatriation operations have not survived. ${ }^{17}$ We thus use partial quantitative information as well as historical evidence to substantiate our interpretation. The existing literature on favouritism and elite capture in Nazi Germany also supports our reading of events. Ferguson and Voth (2008), for example, have shown that firms with ties to the Nazi regime outperformed on the stock market in comparison with firms without such ties. We argue that access to repatriations was an additional channel of rewarding supporters and influential figures. In addition to a reward, repatriations were also a tool of control, which supported the Nazi's totalitarian goals. In a world of strict capital controls private companies were eager to trade more interference in their operations for coveted foreign exchange concessions (Kobrak, 2003).

It should not be surprising that the Nazi party was more than willing to put the bureaucratic might of the state behind its political objectives, even if the overall economic gains were limited or even negative. A counterpoint to the reward of allies in Nazi Germany was the persecution of other groups, above all Jewish Germans. As recently shown by Ritschl (2019), for the systematic dispossession of Jews, and by Huber, Lindenthal, and Waldinger (2020), for the "aryanizations" of private firms, these policies were not the source of any substantial windfall for Germany as a whole, when they were not downright destructive.

In addition to studying both the mechanics and political economy of German debt repatriations, we collect and analyze nine years of weekly spreads between prices of German securities traded in New York and in London ${ }^{18}$ and their equivalent in Berlin. Consistently with our model and our interpretation of the episode, we show that the crucial factor for the origination, variation and persistence of the spreads was the impact of capital controls on private German investors trading on secondary markets.

\footnotetext{
${ }^{17}$ Anecdotal sources report that the vaults and archives of two institutions key to the implementation of capital controls, namely the Konversionskasse and the Golddiskontbank - both offshoots of the Reichsbank -, were located in what became East Berlin and were destroyed or looted upon Soviet occupation. We could not confirm this, but it is known that before the London Debt Conference in 1952 Germany and the US went through a process of verification of which German bonds were held outside of Germany before the end of the war (the so-called Validation Law). This was done to prevent that repayments decided in the London Debt Conference and meant for U.S. creditors would go to holders of looted converted bonds from the Golddiskontbank's vaults (the originals bonds were kept upon conversion) (U.S. Department of State Bulletin, 1952a,b).

${ }^{18}$ For London, we extend with original sources the dataset of Brown and Burdekin (2002).
} 
We thus provide the first complete account of the German repatriations, an episode that has attracted the attention of both contemporary and modern economists. We achieve this by relying on both primary and secondary sources, as well as economic theory. Our primary contribution in this respect is combining the incentives of the German authorities, foreign creditors, and Germans engaging in the repatriations within a fully internally consistent framework.

The rest of the paper is structured as follows. the next section provides an overview of the literature on different theoretical aspects touched upon in this paper. Section 3 presents a model of debt repatriations under a non-utilitarian government. Section 4 presents relevant background on German debt and the repatriations mechanism. Section 5 presents our case study, subdivided in three fundamental questions, namely i) why did repatriations start as a private initiative in 1931, ii) what explains the price differential between German bonds traded domestically or abroad, and iii) what explains the policy choices of the authorities. Section 6 concludes.

\section{Related literature}

Besides the literature on the German debt repatriation episode ${ }^{19}$, we contribute to several open debates in international macroeconomics and finance. We discuss these below.

Secondary markets. Although recent work has started to highlight the importance of secondary markets for sovereign debt ${ }^{20}$, their role has been largely neglected and is still only partially understood in macroeconomics. In practice, however, secondary markets have played an important role during many sovereign debt crises. For example, it has been argued that in the South American debt crisis of the 1980s secondary markets led to the emergence of a class of small creditors prone to litigation that endangered the results of "the collective negotiation and debt restructuring so crucial to resolving the [...] debt crisis" (Power, 1996). Alfaro and Vogel (2006), on the contrary, argue that hold-out creditors could positively impact sovereign debt markets by demonstrating the enforceability of contracts; Ahmed and Alfaro (2017) find in an empirical analysis that the impact of hold-out creditors on markets is positive for some South-American countries and negative for others. Pitchford and Wright (2012) propose a model of hold-outs in sovereign debt renegotiations suggesting that trying to limit hold-outs might be unfeasible and would lead to longer debt restructuring delays.

The possibility of debt ownership change through secondary markets is fundamental because it allows foreign creditors to be, at least partially, repaid by selling their claims to domestic creditors, thereby circumventing any block on direct repayments. Only by controlling secondary markets is the sovereign fully able to acquire a discrimination technology

\footnotetext{
${ }^{19}$ For work on the broader issues on the German economy in the 1930s, see Ritschl (2013); Ritschl and Sarferaz (2014); De Broeck and James (2019).

${ }^{20}$ For instance, during the European debt crisis of the early 2010s and its aftermath a considerable portion of sovereign debt was repatriated by domestic agents in crisis countries (Brutti and Sauré, 2016; Beck, Georgiadis, and Gräb, 2016; Della Corte and Federico, 2019; Emter, Schmitz, and Tirpák, 2019).
} 
against repayments to foreign bondholders. This is the core of the Secondary Market Hypothesis put forward by Broner, Martin, and Ventura (2008, 2010), where well-functioning secondary markets serve as an enforcement mechanism for sovereign debt even when default penalties are low. Broner, Erce, Martin, and Ventura (2014) extend BMV by including crowding-out of productive domestic investments because private agents repatriate their domestic sovereign debt instead of investing. Our paper contributes to the literature by bringing these mechanisms to a world with impaired markets, combining the main intuition of $\mathrm{BR}$ with that of BMV and showing how the private incentive to repatriate debt interacts with the social planner's dual objective to avoid that scarce resources leave the country while rewarding the elite.

Creditor discrimination and domestic default. Selective defaults - default episodes in which different categories of creditors are treated differently - are far from rare; on the contrary, a differential treatment of domestic and foreign debtors has characterized over $80 \%$ of all sovereign defaults since 1980 (Erce and Mallucci, 2018). Despite this fact, studies on the topic are few and far between. Most of the literature assumes that domestic creditors enjoy preferential treatment relative to foreign investors. This is not an unreasonable assumption: Reinhart and Rogoff (2014) document that most sovereign defaults are selective against foreigners, and when domestic default occurs it is with low levels of foreign debt. BMV show that this assumption provides the incentive for private domestic investors to repatriate their debt: if the government cannot prevent repatriations, then debt obligations will be enforced as there is no welfare gain from domestic default. This same mechanism underpins the aforementioned Broner, Erce, Martin, and Ventura (2014). Guembel and Sussman (2009) provide a political economy model of sovereign debt where default on foreign creditors happens when debt distribution implies that the interests of the median voter are in contrast with those of creditors. In Erce and Díaz-Cassou (2010) the government can discriminate against either foreign or domestic agents, depending on the source of liquidity pressure, banking intermediation levels, and perceived strength of the domestic banking system. D'Erasmo and Mendoza (2016) study domestic default in a heterogeneous-agents model without secondary markets and no creditor discrimination. They show that default costs and a non-utilitarian social planner are necessary to ensure debt sustainability and avoid a domestic default. Their calibrated model on Spanish data matches the empirical findings of Reinhart and Rogoff on the occurrence of domestic defaults. Erce and Mallucci (2018) document how distribution of debt among domestic and foreign creditors influences selective defaults, together with the role of legal jurisdiction and not only creditor residence. For a general overview of the literature on sovereign debt and defaults, the reader can refer to Aguiar and Amador (2014).

Institutions and political risk. We also contribute to the literature on institutions and political/sovereign risk (Lucas, 1990; Reinhart and Rogoff, 2004; Alfaro, Kalemli-Ozcan, and Volosovych, 2007; Schularick and Steger, 2008). Our case study spans macroeconomic policy, institutions, and sovereign risk, of which transfer risk is a relevant component. While in this literature lower quality institutions lead to higher sovereign risk, which can entail a higher transfer risk through the mechanism of capital controls, we show how capital con- 
trols can reinforce the decline in institutional quality. This paper therefore contributes by providing an example of how relationship-based capitalism affects sovereign risk through institution quality and how capital controls can affect capital flows also indirectly by enabling institutional decline in the first place, possibly in a positive feedback relation.

\section{$3 \quad$ A model of debt repatriations}

\subsection{Model}

We consider an optimization problem where a government must allocate an endowment of a scarce resource $W$ - foreign reserves - between public spending $G$ and an amount $X$ earmarked for private debt repatriations. The timeline of events is summarized in Figure 2.

$X$ is given to a group of citizens ${ }^{21}$ who are thus authorized to carry out debt repatriations and make a profit on the operation: capital gains are realized by buying the debtor's country private debt in international markets - if it trades at a discount - and reselling it on the domestic market where it trades at face value. The difference in price stems from capital controls, which affect repayments to foreigners but not to domestic citizens. Every citizen inherits a unit of debt issued in a previous period to foreign creditors so that total debt $D_{0}$ also represents debtor population size. All debt is private and when issued it is pooled together from all citizens and securitized at no cost, so that every unit of debt traded both in the primary and secondary market bundles the same fraction of individual debt from every citizen.

The government of the debtor country sets the degree $\phi_{c}$ of an isolationist policy between zero (complete isolation of the country from international capital markets) and one (complete openness). When the parameter is less than unity, only a proportion of private resources $\phi_{c}$ is allowed to be paid back to creditors, effectively shielding the remaining proportion $\left(1-\phi_{c}\right)$ from being seized by creditors when the debt is due. This amounts to a decision imposed by the government on its citizens to (partially) default on foreign creditors. ${ }^{22}$ The choice of the degree of isolationist policy is assumed to be exogenous to the repatriation problem considered here, for example based on long-term political considerations.

\subsubsection{Government}

The government allocates an endowment of foreign reserves $W$ between two uses, $G$ and $X$, such that

$$
W=G+X
$$

where all quantities involved are non-negative. ${ }^{23} G$ is spending on a public good that

\footnotetext{
${ }^{21}$ Citizens populate the same country and inherit the same amount of debt. We refer to all debtors collectively as the debtor country. Creditors are risk-neutral foreigners who operate in international capital markets.

${ }^{22}$ From the point of view of the creditors, this remains a strategic default.

${ }^{23}$ This is a similar mechanism, though simpler, than Broner, Erce, Martin, and Ventura (2014), where repatriations displace resources for productive investments. This would only give additional reasons to keep
} 


\begin{tabular}{|c|c|c|c|}
\hline $\begin{array}{c}\text { Stage } 1 \\
\end{array}$ & $\begin{array}{c}\text { Stage } 2 \\
\perp\end{array}$ & $\begin{array}{c}\text { Stage } 3 \\
\mid\end{array}$ & $\begin{array}{c}\text { Stage } 4 \\
\mid \\
\end{array}$ \\
\hline $\begin{array}{l}\text { - Citizens inherit debt; } \\
\text { - Endowments are } \\
\text { realized. }\end{array}$ & $\begin{array}{l}\text { - Government assigns } X \\
\text { based on social welfare } \\
\text { function; } \\
\text { - Production of public } \\
\text { good G begins. }\end{array}$ & $\begin{array}{l}\text { - } X \text { is received and paid } \\
\text { for by citizens; } \\
\text { - Repatriations are } \\
\text { carried out. }\end{array}$ & $\begin{array}{l}\text { - Debt repayments are } \\
\text { made; } \\
\text { - Public good delivered. }\end{array}$ \\
\hline
\end{tabular}

Figure 2: Timeline

affects all citizens equally and $X$ is an amount only given to government supporters, a subgroup of all citizens. $X$ is used by the supporters to repatriate domestic debt held abroad so that they can reap private benefits in the form of capital gains. Without $X$, citizens cannot carry out debt repatriation operations and only the government can decide on the amount of $X$ supplied. Isolationist policy $\phi_{c}$ and government control over $X$ represent two different channels of capital controls: $\phi_{c}$ affects debt servicing directly, while control over $X$ impacts secondary markets and therefore limits debt ownership changes between foreign creditors and citizens. Citizens have to pay for $X$ from their own endowments ${ }^{24}$ but this amount does not contribute to $W$ (see Figure 2). The government chooses the socially optimal level of $X$ such that it maximizes $U$, a weighted sum of incomes of two mutually exclusive and collectively exhaustive groups of citizens, namely supporters $s$ and non-supporters $n s$ :

$$
U=\alpha D_{0} \omega_{s} y_{s}[X]+(1-\alpha) D_{0}\left(1-\omega_{s}\right) y_{n s}[X]
$$

The incomes of groups $s$ and $n s$ are $y_{s}[X]$ and $y_{n s}[X]$ respectively, where square brackets denote that they are a function of $X$; $y_{s}$ and $y_{n s}$ will be later discussed in detail. Out of population $D_{0}$, the share of supporters is $\omega_{s}$ and consequently $D_{0} \omega_{s}$ and $D_{0}\left(1-\omega_{s}\right)$ are the group size of supporters and non-supporters, respectively. Finally, $0.5 \leq \alpha \leq 1$ is a structural parameter that represents government preference for its supporters. The social welfare function $U$ should then be interpreted in terms of preferences over groups, while taking into account group sizes. The double-weighing system with $\alpha$ and $\omega_{s}$ in equation (2) denotes the presence of elite capture, where a small group of citizens can have a disproportionate effect on the social planner's allocation of resources. ${ }^{25}$

repatriations under strict control.

${ }^{24}$ For tractability, we assume at parity.

${ }^{25}$ D'Erasmo and Mendoza (2016) offer an example of related work where the social planner is not utilitarian. However, their model does not take group size into account: when the only weight in the social welfare function represents a biased preference for a group over another, group sizes are implicitly taken as equal. Different group sizes are important to describe a variety of historically significant episodes such as i) an oppressed minority (e.g. the Jewish persecution during the 1930-40s in Germany), ii) a minority oppressing the majority of the population (e.g. Apartheid). 


\subsubsection{International Markets and Creditors ${ }^{26}$}

For a given $X$, the remaining amount of outstanding debt $D_{x}$ held by foreign creditors after repatriations is

$$
D_{x}=D_{0}-X / P_{x}
$$

where $P_{x}$ is the post-repatriation price of the debt. Given that repatriations simply amount to purchasing debt on the open market, $P_{x}$ must also reflect the value of debt for creditors who do not sell, that is, the expected repayments at maturity $R_{x}$ divided by outstanding debt post-repatriation

$$
P_{x}=R_{x} / D_{x}
$$

Combining (3) and (4) allows us to gain a clear insight into the mechanism that drives prices after repatriations:

$$
P_{x}=\frac{X+R_{x}}{D_{0}}
$$

Equation (5) tells us that, given a pre-repatriation debt of $D_{0}$, the relation between $X$ and $R_{x}$ is essential for price dynamics. As an example, if $R_{x}$ were unaffected by $X$ then the full amount of $X$ could be seen as a transfer of resources to creditors (through the open-market operation of nominal value $X$ ) that would have otherwise never been recovered by them. Expectations of repayments $R_{x}$ are formed rationally by creditors who possess the same information as government and citizens and solve the government's planning problem. $R_{x}$ is based on a publicly known enforcement technology ${ }^{27} \sigma$ at disposal of creditors, which allows them to seize debtor assets as a function of total private resources net of $X$, conditional on the openness of capital markets ${ }^{28}$ :

$$
R_{x}=\min \left\{\sigma\left[X \mid Y_{p}, \phi_{c}\right], D_{x}\right\}
$$

where $Y_{p}$ is the total amount of private resources in the debtor economy that form the base for the repayment of debt and $\phi_{c}$ is the degree of capital controls exogenously set by the government. Government resources $W$ are outside of creditors' reach.

Function $\sigma$ satisfies conditions $1>\partial \sigma / \partial Y_{p} \geq 0$ and $0 \geq \partial \sigma / \partial X>-1$ meaning that creditors gain from additional resources they can seize in the debtor economy but less than one-for-one. $^{29}$ Function $\sigma$ defines the relation between $X$ and $R_{x}$, whose importance is highlighted in equation (5), and consequently its choice will drive debt repatriation (the

${ }^{26}$ The first two equations of this sub-section are from Bulow and Rogoff (1991) and we use the same notation when possible.

${ }^{27}$ In a strategic (i.e. voluntary) partial default, the threat of enforcement makes the debtor pay the remaining (non-defaulted) debt, i.e. the debtor will be indifferent between having $\sigma$ resources seized or voluntarily repaying the same amount - but not more.

${ }^{28}$ The example of the Konversionskasse previously mentioned in the introduction shows how enforcement might be affected by capital controls.

${ }^{29}$ Intuitively, the value of $\sigma$ cannot be higher than available resources $Y_{p}$, as it represents a costly enforcement process in a case of strategic default. If $\sigma\left[X \mid Y_{p}, \phi_{c}\right]<D_{x}$ when $Y_{p} \geq D_{x}, X=0$ and $\phi_{c}=1$, then $\sigma$ can be interpreted as allowing for subsistence income that has priority over debt repayments. 
amount of $X$ chosen by the government) through its impact on the price, effectively linking $\phi_{c}$ with control over secondary markets. Specifying the relation between a non-zero $R_{x}$ and $X$ also leads to partial repatriations $\left(D_{x}>0\right)^{30}$. An example of a capital controls implementation scheme is shown in equation (7) where we assume creditors seize a positive fraction $\beta$, constant and less than unity, of available resources:

$$
\sigma_{a}\left[X \mid Y_{p}, \phi_{c}\right]=\beta \phi_{c}\left(Y_{p}-X\right)
$$

Function $\sigma$ effectively represents the implementation of capital controls: How exactly do private agents finance the repatriation operations? We are interested in particular in how $X$ affects the availability of resources that can be claimed by foreign creditors.

In our reference case $\sigma_{a}(7)$ the assumption is that a portion $\phi_{c}$ of funds $X$ is taken from domestic resources $Y_{p}$ within creditors' reach (thus reducing their claims through $\sigma_{a}$ ), while the remaining portion $\left(1-\phi_{c}\right)$ of $X$ is taken from funds that are otherwise completely shielded from creditors. The amount $\left(1-\phi_{c}\right) X$ does not reduce creditors' claims through $\sigma$ and we can therefore think of $\sigma_{a}$ as a "neutral" case in which funds $X$ are taken at the same time (respectively in proportion $\left(1-\phi_{c}\right.$ ) and $\phi_{c}$ ) from shielded and unprotected domestic resources $Y_{p}$. This implies that $X$ and $\sigma_{a}$ are always negatively correlated.

The effect of an increase of $X$ on $P_{x}$ is always non-negative, however the magnitude of the price variation ultimately depends on $\sigma$. Different choices of $\sigma$ would give rise to different $\partial P_{x} / \partial X$ even with the same $\phi_{c}$ and $\beta$, therefore allowing different dynamics of $P_{x}^{31}$. This shows that the effect of capital controls on debt repatriations manifests itself not only through the amount of resources involved in the default episode, but, as importantly, also through the structure of capital markets.

\subsubsection{Domestic market and citizens}

Before defining $Y_{p}$, the amount of private domestic resources that plays a role at the macro level, we consider the resources available to each citizen. Citizens are rational and maximize their own income $y_{s, n s}$. Every citizen, government supporter or not, receives the same amount of endowments $\varepsilon$. We remind the reader of the debt securitization assumption and that outstanding debt for each citizen is normalized to one so the total amount of debt in the country, $D_{0}$, also represents population size. Citizens are exogenously divided into government supporters $s$ and non-supporters $n s$, each group respectively of size $\omega_{s} D_{0}$ and $\left(1-\omega_{s}\right) D_{0}$, with $1 \geq \omega_{s} \geq 0$. Citizens have to repay the unit of debt issued in the previous period. Given $\phi_{c}$, after repatriations each citizen will repay an amount $\rho$ :

$$
\rho[X]=P_{x} D_{x} / D_{0}+\left(X / P_{x}\right) / D_{0}=R_{x} / D_{0}+\left(D_{0}-D_{x}\right) / D_{0}
$$

\footnotetext{
${ }^{30}$ To see this, note that when $\beta=0$ (the case of BMV) eq.(5) becomes $P_{x}=X / D_{0}$, which then simplifies in (3) to get $D_{x}=0$. BMV propose a variation of their model (Example 9, page 1544) that allows for what can be interpreted as debt repatriations under impaired secondary markets. However, also in that case all debt is repatriated.

${ }^{31}$ In Appendix A we consider different cases for $\sigma$ and discuss the connection with corporate debt buybacks.
} 
where the second equality follows from equations (4) and (3) applied to the first and second term respectively. The first term represents repayments to foreign bondholders (affected by capital controls), with an outstanding amount after repatriations $D_{x}$ traded at price $P_{x}$. The second term represents total debt repayments made domestically at face value, where $X / P_{x}$ is debt repatriated. Both terms are divided by population size $D_{0}$ so that $\rho$ represents debt repayments per capita.

The government provides a public good $G$ that equally affects all citizens, whose individual private benefit from the public good is $\gamma(W-X) / D_{0}$, where $1>\gamma \geq 0$ is a constant and $W-X=G$ comes from the government budget constraint (1).

Supporter demand for $X$ will be positive if supporters profit from the operation in the form of capital gains. However, when $X$ is positive every citizen (supporter or not) suffers from both i) a decrease in the provision of public good and ii) higher debt repayments $\rho$ to other domestic agents due to the repatriated bonds.

Under full information, each citizen of the supporter group is aware that other supporters want to engage in repatriation operations and will thus internalize the detrimental effects of other supporters' repatriations. Citizens also know that the government is aware of their preferences and that it will allow a non-negative socially optimal amount of $X$ following (2). We assume that, within the group $s$, there is no particular pecking order for the allocation of reserves so that the total amount of $X$ supplied by the government is equally shared among all supporters, i.e. $X /\left(\omega_{s} D_{0}\right)$, and that this sharing rule is known to citizens.

Summing up all the elements discussed until now, we get the individual supporter income $y_{s}$ as a function of $X$ :

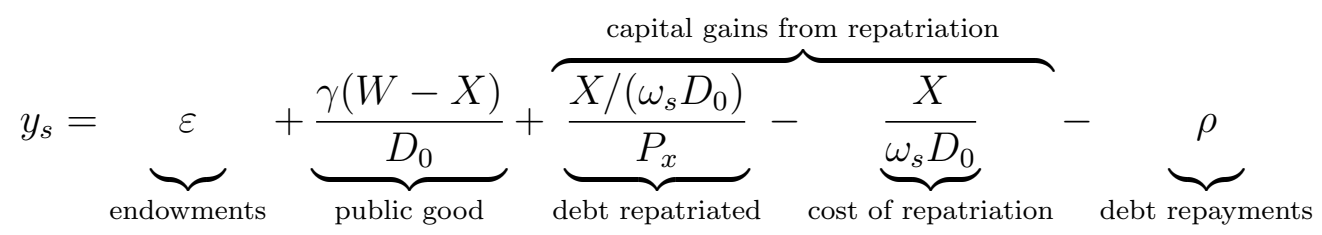

The amount of debt repatriated minus the cost of repatriation form the individual private gains from repatriations, where both terms depend on the individual amount of resources available, namely $X /\left(\omega_{s} D_{0}\right)$. For the second term and in $\rho$, on the other hand, what matters is the total amount of reserves $X$ used for repatriations, as this affects the government budget constraint and aggregate quantities $R_{x}$ and $D_{x}$.

Non-supporters are not allowed to participate in repatriations, so the income for each member of the group, as a function of $X$, is:

$$
y_{n s}=\varepsilon+\frac{\gamma(W-X)}{D_{0}}-\rho
$$

Both $y_{s}$ and $y_{n s}$ are post-repatriation resources so the whole amount cannot be considered as part of $Y_{p}$, the total private resources that form the base of seizable assets. If we exclude capital gains (as they are themselves part of the repatriation operation) and public goods (e.g. roads and armaments) then it is only endowments $\varepsilon$ for the whole population that contribute to term $Y_{p}$, such that $Y_{p}=\sum \varepsilon$, where the summation applies to all citizens. 
For simplicity of exposition we rule out cases of "excusable" default implying that, with no capital controls and repatriations, $\varepsilon$ is enough to cover outstanding debt.

\subsection{Results}

The government chooses $X^{*}$, the optimal value of $X$, by maximizing social welfare (2) subject to resource constraint (1), given: equations (3), (4), (5), (6), (8), (9), (10), structural parameters $\alpha, \omega_{s}, \phi_{c}, \beta, \gamma, D_{0}$, and $W$, and one among (7), (15a), and (15b). We retain $\sigma_{a}$ (7) as our reference case for the proof that will follow as it is "neutral" and easily tractable without loss of generality.

Result 1. A utilitarian social planner, i.e. with no bias for either group $(\alpha=0.5)$, is a sufficient condition for a socially optimal $X^{*}=0$.

Proof. The FOC of the social planner's optimization problem can be written as:

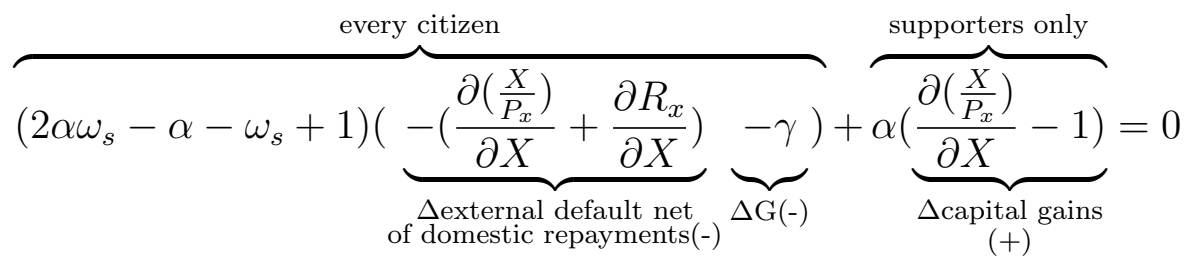

When $\alpha=0.5$, the FOC simplifies to $-\partial R_{x} / \partial X=1+\gamma$, which under $\sigma_{a}$ is $\beta \phi_{c}=1+\gamma$, where, however, $\beta \phi_{c}<1+\gamma$ always holds irrespective of (admissible) parameter values. Therefore, the boundary value $X^{*}=0$ maximizes the social welfare function. It can be easily verified that the same result holds under $\sigma_{b}$ and $\sigma_{c}$ and, more generally, when $-\partial R_{x} / \partial X$ is less than $1+\gamma$.

Result 2. The necessary condition for $X^{*}$ to be positive is $\alpha>0.5$. Under this condition there exist wide ranges of all other structural parameters such that $X^{*}>0$.

Proof. It follows from analysis of the FOC (11) (see also appendix A).

Result 2 can be easily observed in Figure 3. Each boxplot summarizes the distribution of $X^{*}$ for 50625 different combinations of underlying values of the structural parameters, given a value of $\alpha$ and fixing $D_{0}=100$. It shows our main result that when $\alpha=0.5$, $X^{*}=0$ independently of the combination of the other structural parameters. Additionally, it conveys the intuition that the greater the value of $\alpha$, the wider the range of structural parameters that lead to $X^{*}>0$ and the greater the highest attainable magnitude of $X^{*}$ (on the vertical axis). In appendix A we provide evidence for alternative specifications of $\sigma$.

Two important parameters are $\alpha$ and $\omega_{s}$, as they directly and jointly affect the social welfare function. A closer analysis of equation (11) reveals that, indeed, an increase in $\omega_{s}$ always reduces the gains from additional $X$ and is not dependent on $\alpha$. On the other hand, 


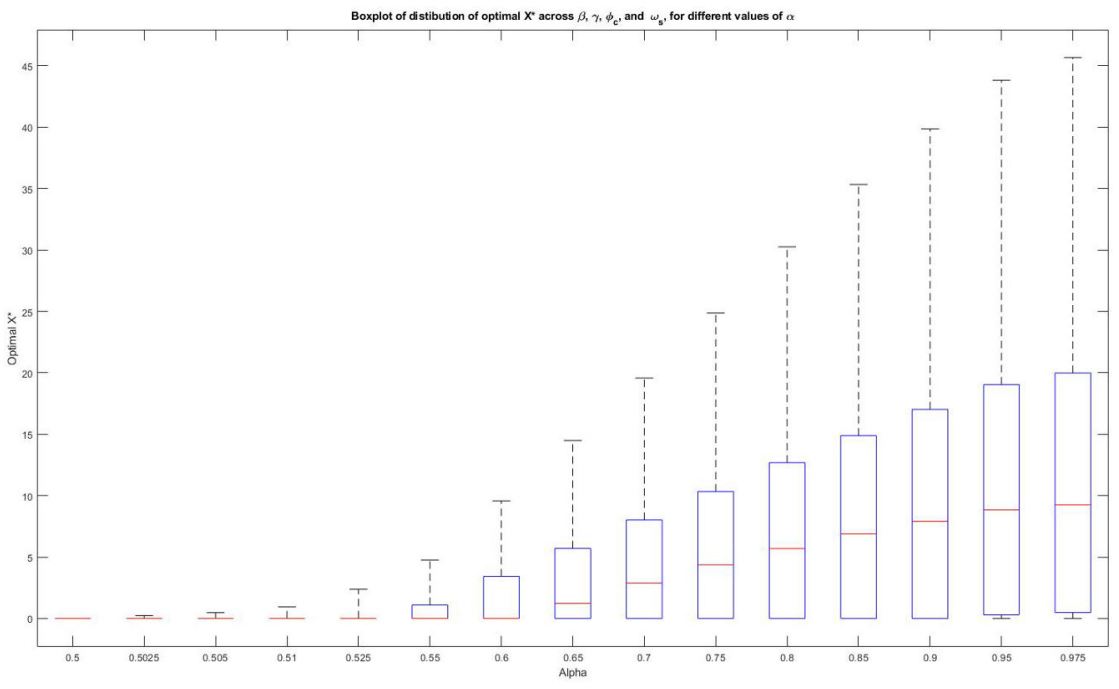

Figure 3: Boxplot of the distribution of $X^{*}$ for different values of $\alpha$.

For each value of $\alpha$, the model is solved for all combinations of 15 values for each of the parameters $\beta, \gamma, \omega_{s}$, $\phi_{c}$, for a total of 50625 grid points for each value of $\alpha$. The 15 values are: $(0.025,0.05,0.10,0.125,0.15$, $0.20,0.25,0.35,0.45,0.55,0.65,0.75,0.85,0.95,0.975)$. Horizontal axis is not to scale.

the magnitude of the effect of an increase in $\alpha$ does depend on $\omega_{s}$ : it is invariably positive when $\omega_{s}<0.5$ and ambiguous otherwise, in the latter case depending also on the values of the other structural parameters. ${ }^{32}$

Figure 4 depicts an example of how the two parameters affect $X^{*}$; the graph is based on specific values of $\beta, \gamma$, and $\phi_{c}$, but it is representative of most combinations of these parameters. In fact, our general results are not driven by the choice of values of other structural parameters. For instance, $\gamma$ is not the main source of detrimental effects of repatriations: a lower value of $\gamma$ (a lower loss of forfeiting public spending) does indeed increase the area in the space $\left(\alpha, \omega_{s}\right)$ where $X^{*}>0$ (i.e. the black contour line in graph $4 \mathrm{~b}$ is pushed up and left) and does not affect the maximum level of $X^{*}$ attainable in that space. However, the detrimental effect of higher repatriations on social welfare remains predominant through the channel of $\rho$ (equation 8).

Both a smaller $\beta$ and a smaller $\phi_{c}$ reduce the maximum $X^{*}$ attainable with any combination of $\alpha$ and $\omega_{s}$, and they both increase the area in the space $\left(\alpha, \omega_{s}\right)$ where $X^{*}>0$. To show this point, Figure 5 plots the percentage of possible combinations of $\alpha$ and $\omega_{s}$ that lead to $X^{*}>0$, as a function of $\phi_{c}$ and for different representative combinations of $\beta$ and $\gamma \cdot{ }^{33}$

The role of $\omega_{s}$ (the supporters group size) stands out when considering a larger group, everything else equal: $\omega_{s}=1$ (all citizens are favoured) corresponds to the case of BR, where collective and group interests match perfectly and therefore $X^{*}=0$. If an individual within

\footnotetext{
${ }^{32}$ See appendix A for further details. and for comparisons with the closest literature.

${ }^{33}$ This is calculated as the area of the projection of the surface $X^{*}\left[\alpha, \omega_{s}\right] \mid X^{*}>0$ on the $\left(\alpha, \omega_{s}\right)$ plane.
} 


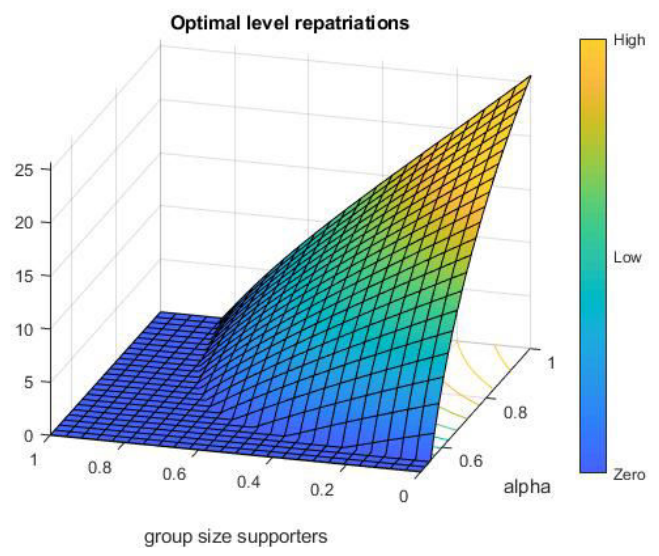

(a) 3-dimensional

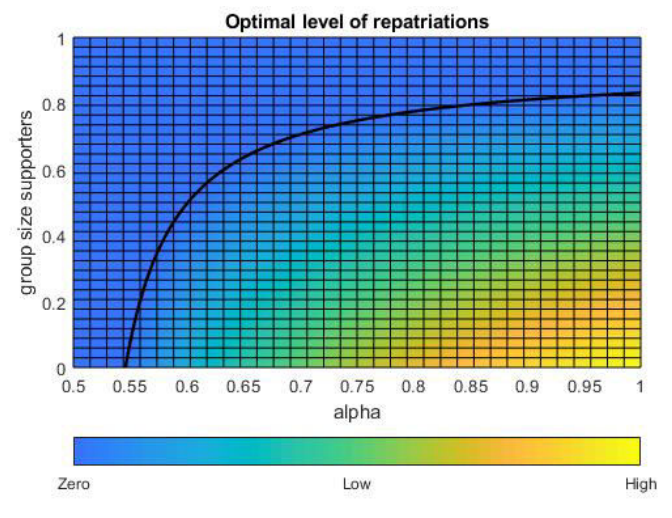

(b) 2-dimensional

Figure 4: A representative example of $X^{*}$ as a function of $\alpha$ and $\omega_{s}$, for given values of $\beta, \gamma$, and $\phi_{c}$. Note that the $\alpha$ axis begins at 0.5 . Black line in right panel is the boundary between zero and positive solution sets.

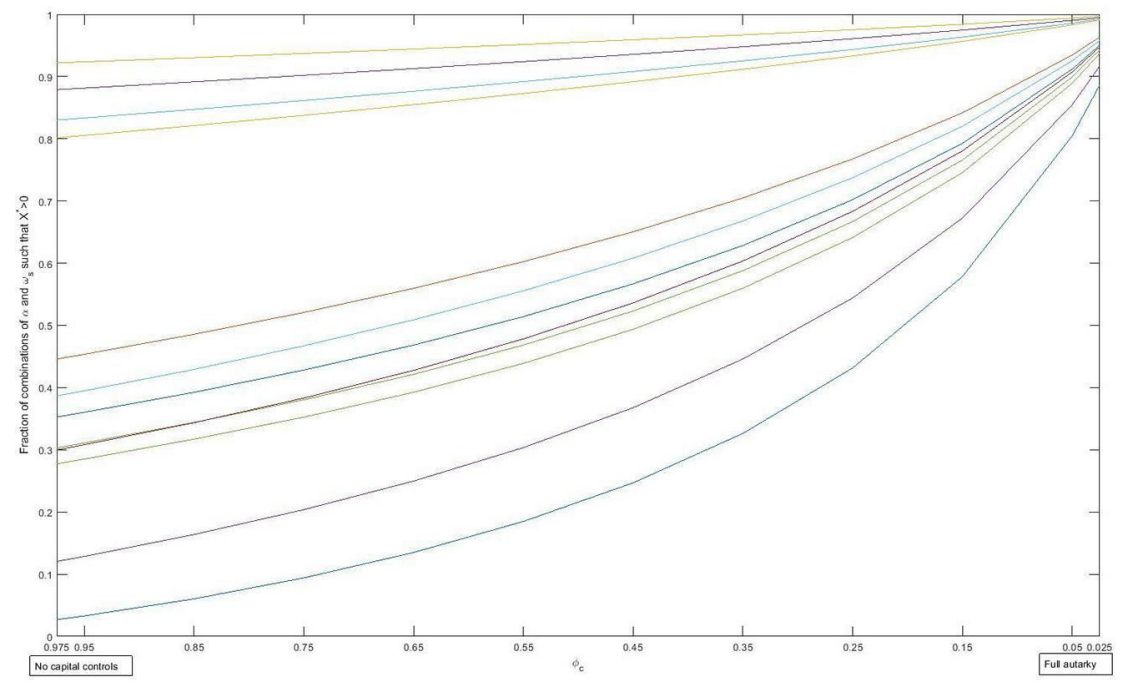

Figure 5: Percentage of possible combinations of $\alpha$ and $\omega_{s}$ that lead to $X^{*}>0$, as a function of $\phi_{c}$ and for different representative combinations of $\beta$ and $\gamma$. Reverse scale for $\phi_{c}$ : moving to the right increases capital controls.

the group could deviate from the government decision, then she would make capital gains at the expense of all others: the government solves exactly this coordination problem. In general, when $X^{*}>0$, the higher the number of citizens allowed to engage in repatriations, the lower $X^{*}$ becomes, until it quickly reaches zero again; note that $\omega_{s}$ need not necessarily reach unity for $X^{*}=0$. This happens because, as $\omega_{s}$ increases, the collective detrimental effects of repatriations in the form of higher domestic repayments in $\rho$ are gradually internalized by more supporters and capital gains cannot compensate for this (eq. 11). Conversely, decreasing $\omega_{s}$ when $X^{*}>0$ will lead to a higher $X^{*}$. 


\section{The many guises of default: German foreign debt and repatriations in the $1930 \mathrm{~s}$}

Having established our theoretical framework, we now turn to the case study: Nazi Germany. In this section we provide the historical background and highlight the main characteristics of the German debt repatriations. The case study complements and supports our theoretical model in three ways. First, we show that the incentives of the actors involved in the repatriations - foreign creditors and German investors - are consistent with those described in our model. Second, we show that elite capture and control can explain the otherwise puzzling actions of the German authorities. Finally, we show that secondary markets played a fundamental role in the German episode, consistently with the secondary market hypothesis of BMV which underpins our theoretical framework.

\subsection{Background}

In the aftermath of World War I, the winning powers imposed a heavy reparation payments burden on a defeated Germany. ${ }^{34}$ The country, however, defaulted on reparations payments practically from the start. Moreover, its policy of passive resistance to the ensuing FrancoBelgian occupation of the Ruhr contributed to the country spiraling into a devastating hyperinflation in 1923, which was brought under control with the decisive contribution of a specially appointed currency commissioner Hjalmar Schacht.

In order to help Germany maintain its monetary stability and meet reparation payments, the Dawes Plan of 1924 established a new reparations payment schedule and a loan ${ }^{35}$ with maturity in 1949, the proceeds of which went to Germany (Clement, 2004). More importantly, however, the Dawes Plan made reparation payments de facto junior with respect to commercial debts. Germany, with its heavy - yet potentially manageable, and now junior debt burden in the forms of reparations, was therefore in the position to attract considerable capital inflows (Ritschl, 2013). As a result, through the second half of the 1920s, all sectors of the German economy borrowed heavily on international capital markets. By the end of the decade, the US was Germany's principal creditor, with holdings of over $40 \%$ of the total foreign private and public debt. Accordingly, the dollar was the principal currency of denomination. Germany's industry was the principal debtor in the country, accounting for almost $62 \%$ of total foreign debts. A large share - around $46 \%$ - of German foreign commercial debt was short term i.e. with a maturity of less than a year. Appendix C.1 provides further details to the interested reader.

\footnotetext{
${ }^{34}$ Its amount - the so-called London Schedule of Payments - was established by the protocol prepared by the Inter-Allied Reparations Commission in 1921, but uncertainty remained as to how much Germany would eventually have to pay. For details, see Schuker (1988).

${ }^{35}$ In the form of seven percent gold bonds, the majority of which were issued in the US and Great Britain, with other minor blocks issued in France, Switzerland, the Netherlands, Belgium, Sweden, and Italy, in the respective local currency. The principal amounted to the equivalent of close to a billion Reichsmarks at the prevailing exchange rates at issuance. The proceeds were paid to Germany in gold and foreign exchange. The service of the Dawes bonds was a direct and unconditional obligation of Germany (Auld, 1934).
} 
This arrangement was eventually reversed by the Young Plan, drafted and adopted between 1929 and 1930. This re-established the seniority of reparations with respect to commercial debts, thus endangering creditors' claims, while also formally ending the hopes of many foreign commercial creditors that a portion of the reparations would be forgiven (Ritschl, 2012, 2013). ${ }^{36}$ By this time, foreign commercial debts had reached 32.6 billion Reichsmarks, and with the inclusion of reparations, Germany's foreign debt in 1930 amounted to 67.6 billion Reichsmarks, or $81.5 \%$ of GDP (Table 1). The inevitable sudden stop of capital inflows in early 1929 was then followed by the start of the Great Depression, which meant that Germany's economic and financial health quickly deteriorated. In 1931, the country experienced a full-blown twin crisis in which fiscal troubles, the foreign debt burden and the fragility of the banking sector fed off each other in a downward spiral (Schnabel, 2004a). ${ }^{37}$ Following a sharp fall in GDP, the foreign-debt-to-GDP ratio reached its peak at the end of 1931 exceeding $100 \%$ (Ritschl, 2013). ${ }^{38}$

\begin{tabular}{|c|c|c|c|c|c|c|c|c|}
\hline Year & $\begin{array}{l}\text { GDP } \\
(1)\end{array}$ & $\begin{array}{l}\text { Reserves, } \\
\% \text { of M0 }\end{array}$ & $\begin{array}{c}\text { Private and } \\
\text { Public Debt } \\
\text { (2) }\end{array}$ & $\begin{array}{l}\text { Reparations } \\
\qquad(\mathrm{NPV}) \\
(3)\end{array}$ & $\begin{array}{c}\text { Total Debt } \\
\begin{array}{c}(2)+(3) \\
(4)\end{array}\end{array}$ & $\begin{array}{c}\text { Debt/GDP } \\
(4) /(1)\end{array}$ & $\begin{array}{c}\text { Repatriations } \\
\text { (5) }\end{array}$ & $\begin{array}{c}\text { Repatriations/ } \\
\text { Debt } \\
(5) /(4)\end{array}$ \\
\hline 1928 & 89.05 & $68.6 \%$ & 27.0 & 40 & 67.0 & $75.2 \%$ & - & - \\
\hline 1929 & 89.25 & $56.3 \%$ & 31.0 & 46 & 77.0 & $86.3 \%$ & - & - \\
\hline 1930 & 82.93 & $61.6 \%$ & 32.6 & 35 & 67.6 & $81.5 \%$ & - & - \\
\hline 1931 & 69.15 & $25.2 \%$ & 33.6 & 34 & 67.6 & $97.8 \%$ & 0.30 & $0.4 \%$ \\
\hline 1932 & 56.44 & $26.7 \%$ & 25.9 & - & 25.9 & $45.9 \%$ & 0.86 & $3.3 \%$ \\
\hline 1933 & 57.72 & $11.4 \%$ & 23.2 & - & 23.2 & $40.2 \%$ & 1.18 & $5.1 \%$ \\
\hline 1934 & 64.38 & $2.2 \%$ & 18.1 & - & 18.1 & $28.1 \%$ & 0.58 & $3.2 \%$ \\
\hline 1935 & 71.75 & $2.2 \%$ & $17.3^{\delta}$ & - & 17.3 & $24.1 \%$ & 0.54 & $3.1 \%$ \\
\hline 1936 & 79.65 & $1.5 \%$ & 16.4 & - & 16.4 & $20.6 \%$ & 0.30 & $1.8 \%$ \\
\hline 1937 & 89.11 & $1.5 \%$ & 14.8 & - & 14.8 & $16.6 \%$ & 0.15 & $1.0 \%$ \\
\hline 1938 & 99.19 & $1.0 \%$ & 13.9 & - & 13.9 & $14.0 \%$ & 0.19 & $1.4 \%$ \\
\hline
\end{tabular}

Table 1: German GDP, foreign debt, and debt repatriations, billions of Reichsmarks.

Source: the debt series is from Bundesbank (1976), the GDP and reparations series are from Ritschl (2013), the debt repatriation series is from Klug (1993) for 1932-38 while the figure for 1931 is our lower bound estimate based on archival evidence from Germany Country File, Bank of England Archive OV34/148: Special advisory Committee Basel 1931 and OV34/179: Germany Moratorium. Report of the committee appointed to examine and interpret the figures submitted by the Reichsbank, May 30th 1933. The large decline in reparations in 1930 is due to the different NPV of the new schedule of payments introduced with the Young Plan. Reserves and M0 (the monetary base) are from Ellis (1940a). Reserves: gold and foreign currency; all values are end-of-year, except for 1928 where the figure for January 1929 is used. $\delta$ : the missing figure is linearly interpolated.

${ }^{36}$ The Young plan superseded the Dawes plan and similarly it provided a new reparations schedule and fresh bonds issuance. The Young bonds were issued mostly in French francs, dollars, sterling, and Swedish crowns. The total amount, at the prevailing parities at issuance, was approximately a third higher than the Dawes issuance. About half was issued in the US and Britain. The Dawes bonds service was maintained.

${ }^{37}$ A large literature exists on the 1931 crisis. See, for example, Ferguson and Temin (2003), Schnabel (2004b), Ferguson and Temin (2004), Temin (2008), Schnabel (2009) and Ritschl and Sarferaz (2014).

${ }^{38}$ The figure in Table 1 refers to mid-1931, when the ratio had not yet reached the $100 \%$ mark. 
The German authorities reacted to the crisis by ratifying exchange controls in the summer of 1931 in order to curb the massive capital flight the German economy was experiencing (Bonnel, 1940; Child, 1958; James, 1985). Their principal feature, which was based on similar legislation in place during World War I and the hyperinflation, was the restriction of the availability of foreign exchange for individuals and companies, which was achieved by giving the Reichsbank a monopoly over all foreign exchange operations (Hahn, 1989). Additionally, the authorities also regulated the use of the foreign exchange they granted. ${ }^{39}$

As Germany's debt crisis unfolded, substantial debt repatriations by German investors began. ${ }^{40}$ Table 1 reports estimates reconstructed by Klug (1993) for 1932-1938. Klug believed pre-1932 repatriations to have been negligible, but our figure for 1931, estimated using archival sources, highlights that the practice was already widespread then. Exchange controls, however, limited the amount of repatriations that could be carried out and led to the appearance of a spread between the price of German securities held abroad and in Germany, since any difference in valuation of the securities between domestic and foreign investors could not be easily arbitraged away.

Concomitantly to these developments, international creditors did attempt to offer some relief to German debtors. On June 21, 1931, US President Hoover introduced a one-year moratorium on German intergovernmental debts and reparations, while the Reichsbank received a $\$ 100$ million emergency loan from other central banks. In addition, the first Standstill Agreement - signed in August 1931 - meant that approximately 6.3 billion Reichsmarks of German short-term debts were frozen (Clement, 2004). ${ }^{41}$ Finally, the Lausanne Conference of July 1932 de facto put an end to reparation payments, hugely reducing Germany's external debt.

Despite these measures and the improvement in Germany's economy, the rise to power of the NSDAP in January 1933 further pushed Germany down the path of external default. The reinstitution of Hjalmar Schacht as president of the Reichsbank in March of the same year, after his 1930 resignation over disaccord on the burden imposed by the Young Plan, and his further appointment as head of the Reichswirtschaftsministerium (Ministry of the Economy) in August 1934 were particularly crucial events, as he was a strenuous and vocal opposer of war reparations (Schacht, 1934; James, 1985). Marking the official start of Germany's foreign debt default, a new Law on Payments Abroad was approved in May 1933. The law forced all foreign debts not covered by the Standstill Agreements - excluding interest and amortization payments for the Dawes loan and the interest payments for the Young loans to be repaid through the Konversionskasse and reduced the service of debts to $75 \%$ of the

\footnotetext{
39 The allocation of foreign currency was at first established based on the requirements of the previous year. In particular, in November 1931, it was established that $75 \%$ of previous year's requirements of foreign exchange would be allocated. In March 1932, the share was lowered to 35\% and successively raised to $50 \%$ (Klug, 1993). This arrangement lasted until 1934 (James, 1985), when even stricter controls on the use of foreign exchange were established (Klug, 1993).

${ }^{40}$ Some debt repatriations also took place in the 1920s, but were quantitatively negligible (Klug, 1993).

${ }^{41}$ The agreement was renewed until 1939 with German debtors only making yearly partial payments.
} 
level of June $1933 .^{42}$

The German government introduced aggressive measures even with regard to the Dawes and Young loans, which had previously commanded a privileged status. In May 1933, notwithstanding the protests of the Bank for International Settlements - the guarantor of these loans - Germany unilaterally revoked the Gold Clause (Clement, 2004). This meant that the loans would now be serviced in nominal rather than in the original gold value basis. The final act came in the spring of 1934, when Germany instituted a complete transfer moratorium - enforced from July of that year - which formalized its default on all foreign obligations (Ellis, 1941).

Although Germany's default was by no means an exception - defaults took place in a large number of countries in Latin America and Europe in the early 1930s - it was the largest of the interwar era (Reinhart and Rogoff, 2013). Moreover, no other country introduced a system of foreign exchange controls that was as strict and pervasive as that of Germany. One of the most striking aspects of this system was that it had all the characteristics of an emergency measure, and were so perceived by most contemporaries, but ended up becoming the defining feature of German foreign economic policy during the decade (Ellis, 1940a). This system was also the foundation of the debt repatriations. By offering to the German authorities the possibility of regulating the allocation of foreign exchange and the access to secondary markets, it gave the NSDAP the chance to both reward and control domestic companies and individuals, thus facilitating the pursue of the party's political goals.

\subsection{The repatriations}

The first element of note with regard to the repatrations is that, as time passed, regulations increased, the control of the authorities over the repatriations tightened and the process became more and more ripe for arbitrariness and the pursuit of political objectives. The second element to consider is that the incentive for German firms and individuals to carry out these operations was their own gain, setting them apart from government-coordinated repatriations (buybacks) episodes such as those that characterized the 1980s debt crises.

Despite their uncoordinated nature, the repatriations were large, reaching their peak at $2 \%$ of German GDP in 1933. This figure, however, still does not fully convey the importance of the episode. Klug (1993) estimates that German debt repatriation amounted to almost $3 \%$ of 1932 global debt (of which Germany had a share of 14\%). To put this in perspective, in the $1980 \mathrm{~s} 4.1 \%$ of the initial stock of debt was repatriated by several countries through coordinated negotiated schemes. In total, as Klug further estimates, $33 \%$ of all German long-term foreign debt was repatriated to Germany, which included 35\% of all long-term dollar-denominated debt. By 1936, German investors had repatriated $40 \%$ of all industrial bonds issued in the US, in addition to municipal bonds, mortgage bonds and other types of bonds.

The regulations surrounding the repatriations were many and often revised. ${ }^{43}$ In practice,

\footnotetext{
${ }^{42}$ See Appendix C.2 for details.

${ }^{43}$ As Ellis (1940a, page 9) recounts, there were "three general exchange-control laws, upwards of 50 separate
} 
however, these operations could be carried out in three main ways with the same fundamental economic repercussions.

First, firms and individuals could directly request foreign currency to engage in a profitable repatriation operation. The decision regarding the allocation of foreign exchange was carried out by the regional tax authorities where the applicant resided following the guidelines of the German Minister of the Economy in conjunction with the German Minister of Finance and the German Minister of Agriculture (Hahn, 1989). Any funds granted would be earmarked for a specific operation that would then be reported back to the Reichsbank. Before the stricter exchange controls implemented in 1934, domestic agents could bypass direct approval by the authorities by buying foreign currency already eligible for repatriations (at a substantial premium over standard foreign exchange) on the market. This aspect will be further discussed in section 5.1.

Second, firms could also engage in repatriation operations by using part of their export proceeds. If a company could demonstrate that its production costs exceeded world prices, the Reichsbank may have granted it the possibility of purchasing German bonds. The system thus essentially represented a way to depreciate the Reichsmark on some export markets, while avoiding depreciation of the nominal exchange rate (Katona, 1934).

Whether purchased in simple financial transactions or through export proceeds, and whether by the original issuer or another agent, the bonds could be converted into domestic bonds after repatriation. ${ }^{44}$ Following conversion, the bonds would be serviced in Reichsmarks and, from June 1934, could be sold on the domestic stock market.

The manner of repatriation also did not matter for the the gains to be realized. If the buyer was not the original issuer, the bond could be either held to maturity or sold on at the higher prices prevalent in Germany. If the debt was purchased by the original issuer, accounting profits could be realized by extinguishing the bonds bought back below face value (Kobrak, 2003). ${ }^{45}$ Besides accounting profits, it bears repeating that the blanket external default enforced by the sovereign might not have served the needs of individual debtor companies. They might have wished to continue servicing their foreign debts to preserve ties with foreign counterparts. Buybacks offered the chance to not completely renege on foreign obligations.

The third and final mode of carrying out repatriations was also tied to exports, the difference being that it involved blocked accounts and scrip rather than bonds and that the Konversionskasse and Golddiskontbank, both entities controlled by the Reichsbank, played an important mediating role between buyers and sellers. Both scrip and blocked accounts were a product of the exchange control system themselves, being essentially arrears of German foreign debt service. This form of repatriations became predominant after 1935 and remained sizable until 1939 (Klug, 1993). In Appendix C.2 we provide details on these type

decrees of amendment and adaptation, and something in the neighborhood of 500 administrative rulings, to say nothing of clearing, compensation, and payment agreements with partner countries".

${ }^{44}$ See Appendix C.2 for details on conversions

${ }^{45}$ On average, only $50 \%$ of the export proceeds were used to repurchase bonds (at least officially), while the rest was compulsorily handed over to the Reichsbank. 
of operations.

Repatriations tied to exports were the object of much debate by contemporaries, mainly because the German government, in the cases when it officially acknowledged repatriations operations, justified them as export subsidies. ${ }^{46}$ Heuser (1934), along with many contemporaries considered repatriations as a genuine way to subsidize German exports; Einzig (1934) wrote that Germany had found a way of "eating [its] cake and keeping it".

However, a number of authors have questioned this interpretation. Balogh (1938), Ellis (1941), and Child (1958), for example, concurred on the fact that repatriations only gained some importance in trade policy by mid-1932, while the practice had already started in 1931. Ellis also expressed doubts as to whether the repurchase of bonds and blocked accounts could be directly linked to genuinely additional exports, especially after 1933, when the perpetuation of exchange controls ceased to have an economic rationale and was, instead, based on political objectives of the National Socialist regime. He also highlighted the arbitrariness of the export subsidy procedure, akin to that present in the direct allocation of foreign exchange to private individuals (Ellis, 1940b). Finally, Klug (1993) provided archival evidence that the Economics Ministry did not consider the price differential between New York and Berlin to be high enough for the additional export practice to be beneficial, given the foreign exchange shortage faced by Germany.

More fundamentally, the use of repatriations - whether of bonds, blocked accounts or scrip - as subsidies rested on their limited scope. Unrestrained or large-scale repatriations would have rapidly eroded the price spread between Germany and financial centers abroad, thus reducing or eliminating arbitrage profits for German exporters. In light of these considerations, the use of repatriations as a large-scale export promotion tool is ruled out.

Klug (1993) offered a very different interpretation of the repatriations, seeing them as a policy tool to reduce Germany's foreign debt overhang. He claimed that the secrecy of many repatriation operations allowed for a significant spread between prices in Berlin and international financial centers to remain independently of the amount of repatriations. If international creditors were indeed unaware that assets they sold were being repatriated to Germany, they would have sold at ex ante price rather than ex post prices. ${ }^{47}$ According to Klug, Germany managed to reduce its foreign debt burden through these operations, even if only marginally: an estimated $2 \%$ of the face value of its 1933 debt stock. This reading of events stands in contrast with the open-market framework of Bulow and Rogoff (1988, 1991), in which the knowledge of the repatriations allows creditors to extract benefits from the operations. It also clashes with the notion that, in order for secret repatriations to lead to meaningful macroeconomic benefits, they need to be extremely large (Cohen and Verdier, 1995).

Some German entities did indeed engage in large repatriation operations. The largest

\footnotetext{
${ }^{46}$ For example, in this memorandum prepared in English by the German Government: FOLIO FHG/3: The Repurchase of German Foreign Bonds, Berlin, January 26, 1934, London School of Economics and Political Science Archive.

${ }^{47}$ In our model, as in BR, this would mean that the term $D_{x}$ in (3) does not reflect anymore the true size of outstanding debt. For more on the mechanics of secret buybacks see Cohen and Verdier (1995).
} 
and most notorious was orchestrated by Goebbels in 1933 to replenish the empty coffers of the Nazi party. The operation, which relied on foreign middlemen, namely Colonel Francis Norris and Siegfried Wreszynski, was relatively successful in achieving its primary goal by repurchasing debt throughout Europe and possibly the US. Contrary to Klug's claim, however, it is clear from the contemporary press that creditors knew that German debt they sold was being repatriated. Norris and Wreszynski already enjoyed a reputation as thawers of frozen German debts and, towards the end of their operation, this was very public information $^{48}$. The secrecy of the operation simply rested in the origin of the funds used for the operation and the final beneficiary of the scheme, and the operation was eventually dismantled by French and British security services in May 1934. Additional evidence that this was not a secret operation are press reports from the time claiming that the sales price of these large repatriation operations was significantly higher than the going market price, a fact consistent with the open-market framework of our model (equation 5) and contrary to Klug's secret-buyback framework. Moreover, the goal of the operation was clearly not debt reduction $^{49}$ and, large as it was, it did not have a macroeconomically relevant dimension. The fact that the Nazi party itself could not carry out such a scheme to full fruition shows the sheer difficulty of such secret operations.

As we further elaborate below, the existence of such an orchestrated operation can be easily explained with our preferred interpretation of elite capture: the NSDAP was part of the institutional machinery and it needed to be favoured as much as other important figures of the time. We also note that, in the same period of time of the "secret" Norris-Wreszynski operation, Finance Minister Count Schwerin von Krosigk was granted only half the amount of foreign reserves he had privately applied for to carry out a repatriation operation: if anything, this shows that a pecking order within the elite was present and that scarcity of reserves was effectively binding.

Klug's cure for overhang interpretation has other shortcomings. First, while German foreign debt did indeed fall sharply during the 1930s - commercial debt was more than halved, going from $40 \%$ of GDP in 1930 to $14 \%$ in 1938 - debt repatriations were a small part of this reduction. $^{50}$ Additionally, the Lausanne Conference of 1932 had put an end to war reparations, further and drastically reducing Germany's foreign debt burden independently of repatriations. Due to the reduction in external debts and the recovery of the economy, Germany arguably stopped facing a debt overhang sometime in 1932-33. Thus, when overhang reduction was most needed, repatriations were scarcely used as a policy tool and they continued long after Germany stopped facing a crushing foreign debt. ${ }^{51}$

\footnotetext{
${ }^{48}$ Fast Thawers, Time magazine, April 9, 1934. For more details, See Appendix C.2.

${ }^{49}$ Bank of England, OV34/85, Colonel Norris (Siepmann memorandum), March 11, 1936, from Klug (1993).

${ }^{50}$ Of much greater importance was the departure of the USA and Great Britain - and eventually all countries from the Gold Standard, which led to sizable devaluations of German debt denominated in foreign currency.

${ }^{51}$ The wider experience of the 1930s debt crisis would appear to lend support to Klug's interpretation: "[...] market-based debt reduction made a useful contribution to resolving the debt crisis of the 1930s by reducing the debt overhang and eliminating marginal creditors" (Eichengreen and Portes, 1990a, page 4). However, the authors do not mention Germany at all in their assessment, even though it carried out the largest repatriations by far, probably because the US and the UK did not fit the definition of marginal creditors.
} 
Second, the government and Reichsbank managed to impose their complete control on the repatriations only after the transfer moratorium of 1934 (Ellis, 1940a). Before that, the Reichsbank President Hans Luther expressed disappointment for the failure of the German authorities to curb debt repurchases more effectively, while the Ministry of the Economy, although viewing the practice with more favor, was also eager to keep it under strict control (James, 1985). Thus, repatriations came under the undisputed dominion of the authorities after their usefulness as a macro policy tool to reduce the debt overhang had waned.

Third, the use of debt repatriations to reduce the foreign debt burden appears even more unlikely for a country heading for political and economic isolationism and marching in rapid steps towards war. Some recorded debt repatriations, principally of Austrian debt, took place as late as 1944 (Klug, 1993). It is unclear what the value of foreign debt reduction would have been to Germany as the 1930s progressed, and even less why the German government would want to reduce Austria's foreign debt in the midst of World War II.

Finally, Klug himself showed that, if the debt repatriations led to any reduction in the market value of the German foreign debt, then this was minimal because market prices did respond, albeit imperfectly, to these operations. A government-sanctioned decade-long mobilization of thousands of individuals and companies, as well as billions of Reichsmarks, to bring about a minimal reduction in the value of the foreign debt appears highly unrealistic.

\section{Debt repatriations in Nazi Germany: our interpre- tation}

Having discussed the historical background and practical functioning of the repatriations, as well as the existing literature on the episode, we now provide our own comprehensive interpretation. We draw on the existing literature, new quantitative and qualitative evidence and our theoretical framework to answer three key questions. 1) Why did the repatriations start in 1931? 2) How can the behavior of German authorities be explained? 3) What explains the price differential between German bonds traded at home and abroad? This breakdown is, in some ways, artificial, as the answer to each of the three questions relies on the others to provide a comprehensive and internally consistent overall picture. Nonetheless, it is useful to organize the narrative and evidence.

\subsection{Why did the debt repatriation start in 1931?}

The reasons behind the start of the repatriation of German debt securities represents the least controversial element of this historical episode. Germany's spiralling descent into the Great Depression described in Section 4 explains why default risk on German foreign debt increased dramatically between 1929 and 1931. At the same time, however, German investors perceived a widespread internal default as less likely for both political and economic reasons (a point that will be further discussed in Section 5.2). The differing default risk led to 
a different valuation of debt securities between domestic and foreign investors. ${ }^{52}$ On one side, this spurred foreign investors to liquidate their holdings of German debt and recoup what they could through secondary market sales. On the other, it led German individuals and companies to purchase German securities abroad to hold them to maturity, sell them on or extinguish them in case they were the original issuer. As a result, large-scale debt repatriations started as an entirely private initiative in 1931.

In the summer of the same year, however, the authorities began regulating and restricting the access of German investors to secondary markets with the introduction of exchange controls. Bondholders, while publicly deprecating debt repatriations, held a favorable stance in private, and interferences in the functioning of secondary markets were seen with hostility. A statement by the Council of Foreign Bondholders from 1937, for example, declared that restraints of bond repurchases would be met with "strong and [...] effective criticism on the ground that, by limiting the market in such bonds, it would act detrimentally to the bondholders" (Eichengreen and Portes, 1990b). The Creditor Representatives were even more explicit about the benefits of the repatriations declaring in 1934 that "German manufacturers and German debtors are benefited, as also are the foreign creditors, the holders of German dollar bonds, the demand for which at improved prices has been considerably increased as a result of these transactions." 53 Contemporary commentators also understood the detrimental effect of secondary market restrictions for creditors. Einzig (1934), for example, identified them as a severe blow to creditors' hope of ever seeing full repayment. This evidence, coupled with the quantitative analysis of bond prices in Section 5.3, reinforces our argument that secondary markets (in our model, $X$ ) can mitigate or even offset the effects of reductions in creditors' expectations of repayments, $R_{x}$, and are therefore of great importance to creditors (this is the crux of the Secondary Market Hypothesis).

By restricting access to secondary markets for German citizens, the exchange controls led to the appearance and persistence of a spread between the price of German securities traded domestically and internationally (again, see the quantitative analysis in Section 5.3). This, however, also increased German investors' incentives to participate in secondary markets as the potential for large arbitrage profits materialized. ${ }^{54}$ In fact, even with the authorities increasing their control on the repatriations, private sector initiative remained dominant. In

\footnotetext{
${ }^{52}$ Different assessments of sovereign risk between domestic and foreign investors are not uncommon (Eaton, Gersovitz, and Stiglitz, 1986; Claessens, Diwan, Froot, and Krugman, 1991) and are justified by the actual differential treatment domestic and foreign creditors often receive (Broner, Didier, Erce, and Schmukler, 2013; Erce and Mallucci, 2018). In our model, this is reflected in creditor expectation $R_{x}$.

${ }^{53}$ Opening Statement of the Creditor Representatives, Berlin May 4 1934, via Klug (1993, Page 37). Interestingly, the US government demonstrated its support for the continuation and extension of the exchange controls at the London Conference of 1931. The measure was seen with favor by the Americans presumably because it stopped the liquidation of short-term loans (at this point the Standstill Agreement covered less than half of all short-term debts and the exchange controls were still rather porous), which might have endangered the repayment of long-term debts, which constituted the bulk of American credit in Germany (The Economist, July 25, 1931, p. 160, via Ellis (1940a); Auld (1934)).

${ }^{54}$ In the model, this sequence is represented by the government setting $\phi_{c}<1$, which then leads to a positive capital gain term appearing in equation (9).
} 


\begin{tabular}{lclc}
\hline \multicolumn{2}{c}{1933} & \multicolumn{2}{c}{$\mathbf{1 9 3 4}$} \\
\hline Month & Premium, \% & Month & Premium, \% \\
August & 122.0 & January & 148.5 \\
September & 124.8 & February & 149.5 \\
October & 125.0 & March & 153.0 \\
November & 120.5 & April & 158.5 \\
December & 129.5 & May & 156.5 \\
& & June & 200.0 \\
& & July & 215.0 \\
& & August & 250.0 \\
\hline
\end{tabular}

Table 2: Premium for Foreign currency eligible for debt repatriations over regular foreign currency.

Source: U.S. Tariff Commission, Foreign Trade and Exchange Control in Germany. Report No. 150, 2d Series. Washington 1942, via Child (1958, page 118-119).

1933, for example, a vibrant market emerged in which currency eligible for repatriations sold at large and growing premiums over regular foreign currency exactly because of the potential arbitrage profits of repatriations (Table 2). However, this market also had the unintended consequence of aiding the concentration of the repatriations in the hands of a few large banks, "which facilitated control by the authorities on which types of securities could be repatriated" (Child, 1958, page 118-19). The market ceased to exist altogether with the provisions of Schacht's New Plan of August 1934, which made "eligible" foreign exchange (i.e. foreign exchange which could be used for the repatriations) non-transferable. However, repatriations did not stop as authorities continued to set aside and distribute substantial amounts of foreign exchange, relative to available reserves, for such operations at least until 1939.

\subsection{How can the behavior of the German authorities be explained?}

The behavior of the German authorities represents the most puzzling and controversial element of the episode. If repatriations were, indeed, a transfer of scarce resources to foreigners, why were they not suppressed altogether? Why was coveted foreign exchange put aside for these operations? Why would a country marching towards war and autarky after the NSDAP came to power continue allowing repatriations well into the late 1930s?

In Section 4.2, we ruled out the use of repatriations as macroeconomic policy tool for export stimulation and/or debt reduction. Any benefit which could be extracted from the repatriations depended on their limited use and the resulting persistence of the price differential of German securities between home and abroad. This, combined with the impossibility of keeping any large repatriation operations secret, meant that only a limited and selected portion of Germany's population and companies could stand to gain from the repatriations.

Consequently, we argue that limited and tightly controlled debt repatriations were a useful political tool for the government. By rationing foreign exchange and controlling its use, the German authorities were able to rule out large scale foreign debt repayment, ensure the existence and persistence of a price differential between securities traded in domestic 
and foreign financial markets and choose who would benefit from being able to carry out the repatriations. Additionally, the granting of foreign exchange for repatriations was used as a tool to obtain leverage and control over individual and companies. This is why we incorporate the idea of elite capture explicitly in our model.

We know that influential industries, individuals and companies did benefit greatly from the repatriations (James, 1985) and that the assignment of foreign exchange, especially as time passed and regulations became more stringent and complex, was highly bureaucratized and arbitrary (Ellis, 1940b; James, 2020). The last Weimar governments, which preceded the Nazi regime, were intertwined with interest groups, such as the land-owning Junkers. Strong connections existed between the NSDAP and the industrialists who provided support for the Hitler's rise to power and offered the material means to fulfill his goal of rearmament and territorial conquest.

It is also well established that favoritism by the NSDAP had economic consequences. Ferguson and Voth (2008) have documented this with reference to stock market performance. As discussed in the Introduction, a counterpoint to this favoritism also existed in the form of the dispossessing and persecution of different sections of the German population, especially Jewish Germans. The economic consequences were not limited to individuals, firms experiencing "aryanizations" suffered in terms of stock prices, dividends and asset returns (Huber, Lindenthal, and Waldinger, 2020). The coercive power of the state was put behind the pursuit of these objectives, even if the economic repercussions were negative.

Granting the possibility of repurchasing foreign debt abroad was another way of favoring supporters and strengthening alliances. Exclusion from these operations was not just a punishment in terms of missed opportunities, but also in terms of net resources transferred abroad, as we have shown theoretically. Rewarding some portion of society while punishing another were so much two sides of the same coin as to even share the same tools: with the New Plan of 1934 the emigration of German Jews was integrated in the blocked account system by transforming the assets of the emigrants into such accounts to be converted into foreign exchange at heavy discounts (Klug, 1993; Ritschl, 2019).

While complete records of repatriation operations have been lost, making it impossible to reconstruct a systematic picture of the favoritism and arbitrariness of the allocation of foreign exchange, we have several examples illustrating these mechanisms. For instance, the company Miag Mühlenbau und Industriegesellschaft - tied to the regime because of its involvement in rearmament - was granted foreign currency in order to buy-back some of its own debt securities from abroad, which bore a particularly heavy interest burden (Klug, 1993). Hermann Abs - an important figure in post-WWII Germany and a Deutsche Bank director in the 1930s - made large personal profits by purchasing German debt abroad and selling it for higher prices in Germany (James, 2004). Two particularly remarkable examples, which we previously mentioned, involved a member of the government and the Nazi party itself. The Finance Minister Count Schwerin von Krosigk carried out a personal repatriation operation in November 1933, but was only granted around half of the foreign exchange he had initially requested (Klug, 1993). The NSDAP, in a period when it was particularly cashstrapped (precisely between Autumn 1933 and Spring 1934), employed foreign intermediaries 
to (secretly) buy large quantities of German debt throughout Europe in order to make profits by selling it at home, an attempt that was only partially successful.

As mentioned, the rationing of foreign exchange also served as a tool to extend the government's control over corporations and the private sector more generally. Desperate to increase their foreign exchange quotas to import raw materials, subsidize exports or simply make arbitrage profits, companies curried the favor of the Nazi regime, cooperating ever more closely with the government to help it achieve its political and economic goals (Kobrak, 2003). ${ }^{55}$

German citizens and companies could also use debt repurchases as a tool to repatriate assets held abroad. Capital repatriated in this way implied no net transfer of resources abroad and, for this reason, met little resistance from the authorities. On the contrary, in a number of cases, the government and central bank were actually actively involved in the repatriation of offshore funds. The Reichsbank, for example, actively supported a number of such operations (Kobrak, 2003).

One more element in the authorities' decision-making process needs to be addressed, namely the selective default decision. As discussed in Section 5.1 this decision underpins the different default probability expected by domestic and foreign creditors and, as such, is an important element of our interpretation of the whole episode. We argue that the German government's decision to implement a sovereign default on foreign creditors involving both public and private debts, while enforcing domestic payments, was in line with the objectives of the NSDAP - autarky, rearmament and territorial expansion - and that investors understood these objectives.

Our view could be contested on the basis of the fact that, just a decade earlier, Germany underwent a massive default on domestic rather than foreign creditors in the form of hyperinflation. How can the radical difference in policy response between the two episodes be explained? Apart from the clear political differences between Germany in the early 1920s a newly established democracy emerging from a traumatic military defeat - and in the early 1930s - a country transitioning from an unpopular and dysfunctional democracy to a nationalistic totalitarian regime - we can also identify an economic rationale, which may be more relevant for late Weimar governments. Following Erce (2012), we can frame the selective default decision based on the following elements: 1) the source of the liquidity pressure, 2) the health of banking system, 3) the sources of financing for the economy.

Almost half of Germany's foreign commercial debt accumulated in the 1920s was shortterm. Towards the end of the decade, rolling over this debt became increasingly difficult, due to the provisions of the Young Plan, the onset of the Great Depression and the deteriorating financial circumstances in the United States and other creditor nations. Thus, the evidence points to a strong liquidity pressure coming from abroad. Additionally, Germany underwent a devastating banking crisis in 1931. This made it very unpalatable for the authorities to impose further pressure on a crippled financial sector in the form of an internal default. Moreover, exchange controls were introduced precisely in order to shield the domes-

\footnotetext{
${ }^{55}$ Revolving doors between the bureaucracy and corporations were not uncommon, and government officials familiar with the foreign exchange laws were particularly sought after.
} 
tic economy and the banks from capital flight. The precarious health of Germany's banking system might have therefore further discouraged the German authorities from not enforcing domestic payments.

While Germany relied heavily on foreign borrowing to finance reparations payments, as well as its public and private sectors, during the 1920s, international financial markets were essentially shut for German borrowers starting from 1929, particularly for medium and longterm loans. ${ }^{56}$ After the deluge in foreign borrowing of 1924-28, the German economy started moving towards trade and financial autarky, especially after the NSDAP ascended to power in 1933. In this context, access to foreign borrowing became of limited importance, paving the way for external default.

To conclude our discussion of selective default, we point out that there was a limited and implicit form of internal default in 1930s Germany. The work-creation and rearmament programs of the National Socialist government relied on financial repression, of which the exchange control system, with its ability to stop outward capital flows, was an important part (Ellis, 1940a). Financial repression meant that short-term assets were transformed into long-term ones through ad-hoc consolidation loans, interest rates and dividends were unilaterally reduced and kept artificially low, and the government employed substantial disguised money printing (through the tools such as Solawechsel and Mefowechsel) to finance growing government deficits in the second half of the 1930s (Poole, 1939).

\subsection{What explains the price differential between German bonds traded at home and abroad?}

The last element of the repatriation episode we tackle is the price differential between German bonds traded domestically and on international financial markets. We proceed in three steps. First, we document this spread in greater breadth and detail than has been done so far by using newly collected weekly data on German bonds prices in New York and in London between 1930 and 1940. Second, we identify structural breaks in the spread employing an "agnostic" methodology ${ }^{57}$ whereby we treat both the break dates ${ }^{58}$ and number of breaks as a priori unknown, to be endogenously determined from the data. Finally, we link each break identified to an important historical event.

\footnotetext{
${ }^{56}$ An important exception is the Young loan of 1930 (Ritschl, 2012) and the fact that, as Ritschl (2001) puts it, "during its first two years Nazi Germany was successful in attracting fresh credit despite the continuation of the standstill agreement and the default of 1933/34 on long term credit. One reason may have been the discrimination against (mostly American) long term debt in favor of continuing service on (mostly British) short-term credits (this is Schuker's hypothesis)".

${ }^{57}$ The nature of the macroeconomic and policy events we investigate is rather broad in scope. For this reason we do not analyze the effect of predetermined lists of events on our series of interest. There would be an intrinsic difficulty in determining what is really the date of the "event" (e.g. due to market expectations or the multiple incremental changes in law enacted in a short period of time) and trying different lists of events invalidates the standard econometric methods as it amounts to multiple testing.

${ }^{58}$ It is important to note that allowing for more than one break requires different, and more complex, statistical procedures than in the well-known case of a single break.
} 
While there can never be absolute certainty about which historical events should be associated with a certain break, we do find compelling evidence that restrictions on secondary market access for Germans played an important role in increasing the spread. We thus find support for one of the fundamental building blocks of our model and interpretation of the case study.

\subsubsection{Data and methodology}

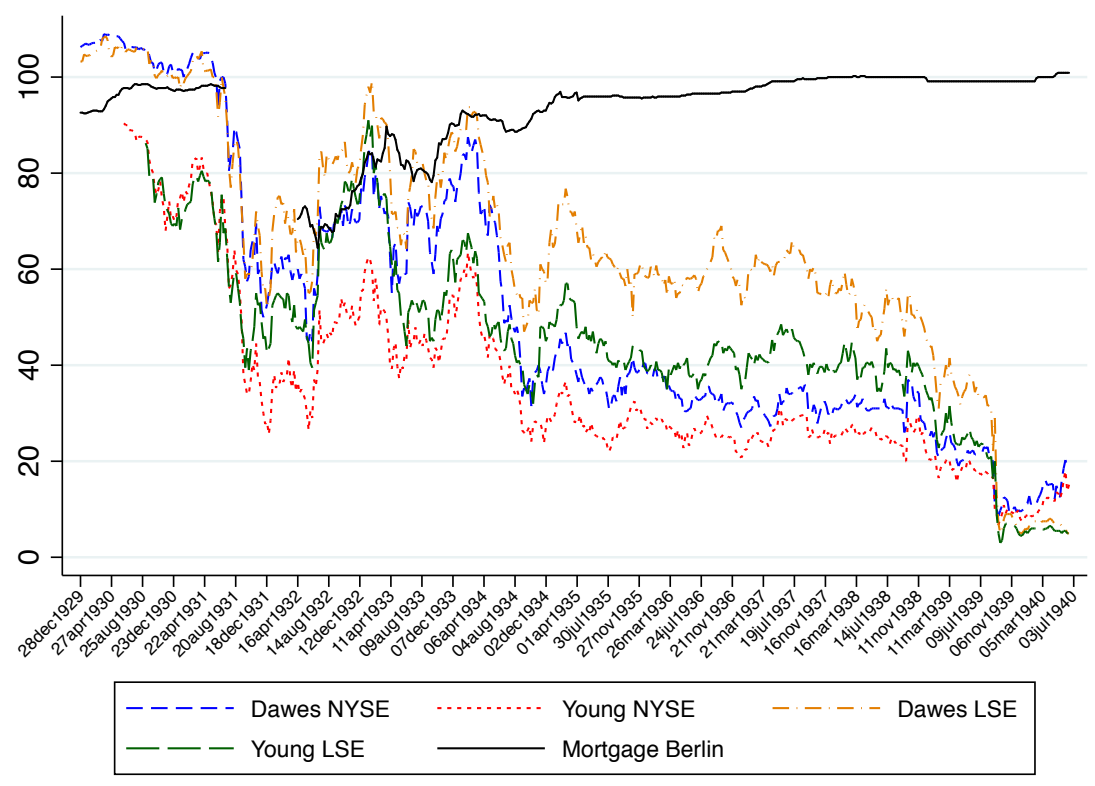

Figure 6: The price of Young and Dawes bonds in New York \& London, and of Mortgage bonds in Berlin. Weekly frequency. NYSE = New York Stock Exchange, LSE = London Stock Exchange. Source: New York, The Annalist (1930-1940); London, The Financial Times (1929-1932) for 1929-32 and Brown and Burdekin (2002) for the rest of the period; Berlin, Global Financial Data (2020).

Figure 6 presents the weekly data for the Dawes and Young bonds traded on the New York and London Stock Exchanges as well as quotations of German Mortgage bonds on the Berlin Stock Exchange. The sample begins in December 1929 (for the Young series it starts in June 1930 in New York and in September 1930 in London) and ends in June 1940. The data was manually collected from the The Annalist (1930-1940) for New York and the The Financial Times (1929-1932) for London until the end of 1932, when we splice it with data from Brown and Burdekin (2002). The Berlin Mortgage bond data comes from Global Financial Data (2020). Two data issues are immediately apparent: i) the series for Berlin is incomplete, as the Stock Exchange was closed from July 1931 to April 1932; ii) in order to work with weekly data, we take the public bonds for which data at this frequency is available, namely Mortgage bonds in Berlin and Young and Dawes bonds in New York and London, as representative of German public bonds and as directly comparable to each other. 
To deal with the first issue, we reconstruct the missing data in the bonds traded in Berlin assuming four different scenarios, all but one involving an eight-week slump in prices correlated to the dynamics of the US stock market. Three of the four scenarios differ in the timing of the start of the slump (ranging from July to August 1931), whereas the dynamics for the rest of the missing subsample are all based on interpolated monthly data of representative German fixed interest securities from the League of Nations Statistical Yearbook 1932-33. The fourth reconstructed series consists in a linear interpolation for the whole missing subsample. We use these four reconstructed Berlin bond series to obtain 16 different spreads series, four for each foreign-traded bond series we study (Dawes and Young) and for each location (New York and London). ${ }^{59}$

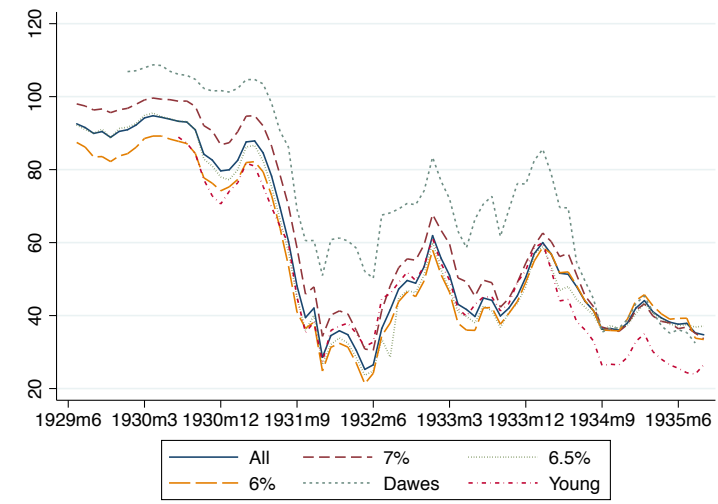

(a) New York

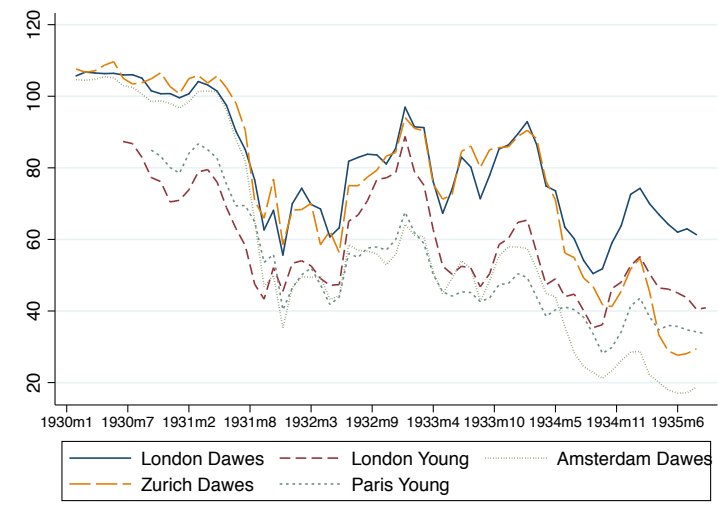

(b) Other international markets

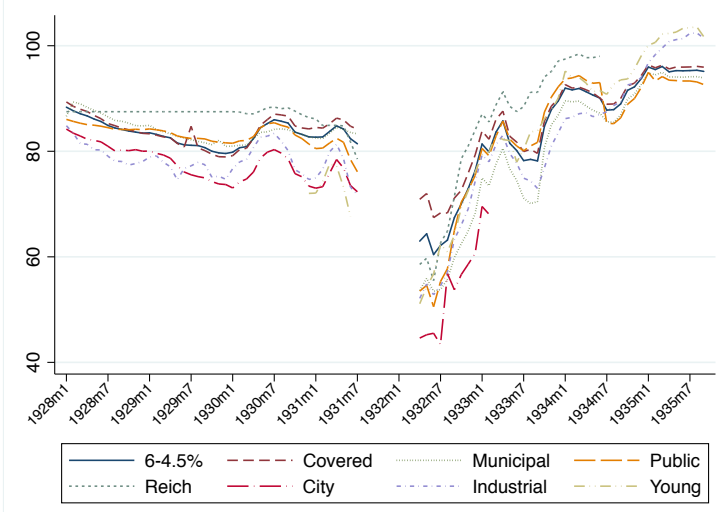

(c) Berlin

Figure 7: The price of German bonds in different financial markets. Monthly frequency. Source: Institut für Konjunkturforschung (1933, 1936).

Reassurance that the second issue - i.e. the representativeness of the bonds and their comparability to each other - is not a problem for our analysis is provided by Figure 7. This

${ }^{59}$ See appendix B.4 for more details. 
reports monthly price data for a wide range of bond types and locations. The lower panel of the figure shows that the monthly prices of different types of bonds traded in Berlin were highly correlated with each other. This applies to both public and private bonds, with a correlation of bond type pairs of between 0.82 and 0.98 . The figure also illustrates that Young and Dawes bonds traded in New York and London were representative of a broad range of German bonds types traded abroad (panel a and b). In New York, for example, the correlation between pairs of bond types ranged between 0.89 and 0.99 . The correlation between German bonds traded in New York, London, Paris, Zurich and Amsterdam was also very high: 0.78 at the lowest and 0.98 at the highest. ${ }^{60}$

The high correlation across bond types and locations has a simple historical explanation: for foreign investors in this period, changes in sovereign risk dominated issues related to specific bond types. Although some differences existed in the treatment of creditors based on nationality - with Brits receiving a more favorable treatment than Americans on average (Eichengreen and Portes, 1988a) - macro developments were similar for all foreign creditors. In fact, while the German government was very keen in claiming a difference between "political" and other debts, in practice the treatment of different categories of debtors was not significantly different (Guinnane, 2004). Moreover, the decision to repay foreign debts, whether public or private, eventually rested with German authorities, making all German foreign debt de facto sovereign. This was also confirmed ex-post by the London Debt Agreement of 1953, in which both private and public German debts from the interwar period were discussed and negotiated jointly. Similarly, in Berlin, common macro developments dominated the evolution of bond prices.

A simple visual inspection of the data in Figures 6 and 7 allows one to conclude that the prices of German bonds traded in Berlin followed a very different path compared to similar bonds traded abroad. First of all, their price recovered much faster after the crash of 1931. Secondly, their co-movement with bonds traded abroad broke down in the first half of 1934, with bonds in Berlin trading at stable prices close to face value and internationally-traded bonds exhibiting volatile and decreasing prices.

We show that these developments are also picked up by statistical tools. We follow the dynamic optimization procedure of Bai and Perron (1998, 2003), which estimates the break dates of a univariate process for a given number of breaks, after having tested for the optimal number of breaks with a battery of different tests. We assume an autoregressive process ${ }^{61}$ of

\footnotetext{
${ }^{60}$ The privileged status of Young and Dawes loans compared to other foreign loans, which gave them a certain degree of seniority over other debts at least until 1933 (Clement, 2004), is also not problematic for our analysis. This is because it shielded these bonds from fluctuations due to temporary shifts in economic conditions, policy, and creditor expectations, making the structural breaks we find more reliable.

${ }^{61}$ The choice of a first-order autoregressive model permits us to use a reasonably flexible, yet easily tractable model. It's not possible to assume a unit root process as we are potentially considering multiple breaks and even sophisticated tests found in the literature cannot be applied in this case (e.g. Kejriwal, Perron, and Zhou (2013)). The appropriate test would be one which tests the null of a unit root with multiple breaks against the alternative of a stationary process with multiple breaks but, to our knowledge, such a test exists only for cases with up to two breaks (Lee and Strazicich, 2003) and not for an arbitrary number of breaks. We could have therefore simply assumed stationarity of the series under each regime, but since
} 
the first order, in which the constant term and the autoregressive coefficients of the model are both subject to structural breaks. This means that we allow for breaks both in the level and the persistence of the process. We also control for local market conditions with an exogenous regressor that reflects the evolution of the respective stock market. The interested reader can refer to appendix $B$ for technical details.

Besides break dates, we also provide asymmetric 90\% confidence intervals around the breaks, which allow us to identify historical events within a reasonable time interval rather than a single date. This is particularly useful in periods where, as will be discussed, multiple policy interventions of the same nature took place in a short period of time.

\subsubsection{Results}

Across all 16 spread series, there is support for a number of break dates varying between four and seven. We present results when allowing for the highest number of breaks reasonably supported by each model. Our estimation of the structural breaks yields remarkably consistent results across different locations - London and New York - bond types - Young and Dawes - and assumptions regarding the evolution of the Berlin bond prices during the closure of the stock exchange. Full results for each spread series, including break dates and confidence intervals, are reported in Appendix B.2. The results are further robust to different specifications of the models, ${ }^{62}$ to the use of a different stock index for New York, as well as the series of interest being the price level of the Dawes and Young bonds abroad instead of the spread.

We summarize the key findings of the analysis in Table 3. For each identified break, the table shows the earliest and latest point estimate of the break date across all 16 models. More precisely, because we use end-of-week data, we provide the date of the Saturday of the first week of the new regime following a structural break. The table also reports the historical event associated with each break, as well as whether this led to a higher or lower spread.

Critical junctures in Germany's history in this period appear as structural breaks. For example, we clearly identify the impact of the Lausanne Conference of 1932, the reinstatement of Hjalmar Schacht as president of the Reichsbank and the start of World War II in 1939. That we are able to pick up these episodes, which had clear bearing on the repayment probability of foreign creditors, is reassuring and lends credibility to our empirical strategy. However, most importantly for our purposes, the majority of the breaks are associated with events featuring the introduction and strengthening of exchange controls. Thus, many of the events we find to be important for the evolution of the spread are set apart from other important economic and political landmarks in Germany's default by the fact that the access of German citizens and companies to secondary markets for debt abroad was restricted. This is consistent with secondary market hypothesis and, thus, also with our theoretical approach.

\footnotetext{
we are interested in the short sample properties of each regime it would most likely be an assumption of no consequence.

${ }^{62}$ See appendix B.3 for details.
} 


\begin{tabular}{llll}
\hline $\begin{array}{c}\text { Break } \\
\#\end{array}$ & Event & $\begin{array}{l}\text { Earliest and latest break week } \\
\text { among all models }\end{array}$ & $\begin{array}{c}\text { Effect on } \\
\text { the spread }\end{array}$ \\
\hline 1 & Introduction of exchange controls & 11 April 1931 - 10 October 1931 & $\uparrow$ \\
2 & Cancellation of reparations (Lausanne Conference) & 11 June 1932 & $\downarrow$ \\
3 & Reinstitution of Schacht as Reichsbank president & 11 February 1933 - 4 March 1933 & $\uparrow$ \\
4 & Transfer moratorium and strengthening of exchange controls & 3 March 1934 - 5 May 1934 & $\uparrow$ \\
5 & Further strengthening of exchange controls & 14 July 1937 - 4 September 1937 & $\uparrow$ \\
6 & New foreign exchange controls announced and implemented & 1 October 1938 - 31 December 1938 & $\uparrow$ \\
7 & Germany invades Poland and World War II begins & 26 August 1939 - 2 September 1939 & $\uparrow$ \\
\hline
\end{tabular}

Table 3: Historical events corresponding to the break dates in the German bonds spread series. For full results, including confidence intervals for each of the breaks, see Appendix B.2.

The first break we find corresponds to the start of the German debt crisis and of exchange controls system in the summer of 1931. This break date is not estimated as consistently across different models as the other breaks for two main reasons.

First, the break corresponds to the period in which the German stock exchange was closed and, therefore, the period in which we had to reconstruct the spread between the prices of the bonds based on a variety of probable scenarios. This reduces the likelihood of identifying a clear break in this period (see Appendix B.4). Reassuringly, however, we find very similar break dates when we perform our analysis just on the foreign debt price levels rather than the spread, indicating that the reconstruction of the data is not driving the results. This is also in line with our interpretation and theoretical framework, which indicates that most of the action should come from changes in the expected probability of repayment of foreign creditors when affected by a change in the access to secondary markets by the debtors.

Second, although in retrospect we can clearly identify the date in which Germany's exchange control system came into being, at the time a large degree of uncertainty existed on the nature of the controls. The measure was widely seen as temporary, and provisions to make the controls effective were introduced only gradually as Germany's crisis deepened (Ellis, 1940a), helping to explain why different models pick up different weeks for the start of this new regime. Nonetheless, our statistical procedure clearly identifies a structural break in this crucial period, unambiguously indicating a worsening of the prospects of repayment for foreign creditors in connection with the first restrictions on trading on secondary markets.

While the drop in the price of German bonds also clearly reflects the general disarray of the German and world economy, we argue that exchange controls were particularly problematic for holders of German securities abroad, and that this explains the structural break we find. Debt repatriations had given the opportunity to foreign investors to dispose of assets whose default risk had increased. Facing a lower probability of default or the possibility of posting profits thanks to prices well below face-value, German investors and companies were willing counterparts in these transactions. The introduction and tightening of the exchange controls, however, made these transactions increasingly difficult.

The second break we identify is the only one connected with a decrease, rather than an increase of the spread. This is not surprising since the break is clearly linked to the Lausanne 
Conference of June-July 1932, which, de facto, put an end to war reparation payments, thus raising the expected value of the remaining serviced debts, including Dawes and Young bonds.

We identify a further downward break in February/March 1933, in correspondence with the reinstatement of Hjalmar Schacht as head of the Reichsbank. Schacht was a complex figure: at the same time a staunch opponent of reparations - he also believed the Young loan to have been imposed on Germany immorally (Schacht, 1934; Clement, 2004) - and a friendly figure in international financial circles. His actions after 1933, despite some windowdressing, were unambiguously bad news for foreign investors, however, and his hostility to foreign creditors even more explicit than that of his predecessor. Even before the transfer moratorium and the consolidation of exchange controls as a totalitarian tool of control in 1934, he took important steps that reduced the foreign exchange available for debt repatriations and foreign debt service. In particular, his first act as new Reichsbank president was the unilateral decision to repay a large loan his predecessor had obtained from foreign central banks, which had represented a much-needed foreign exchange reserve buffer for the Reichsbank and a guarantee of at least partial service of commercial debts.

The complete transfer moratorium and the introduction of even tougher exchange controls in 1934 are connected to a further collapse in the bond spread and to the fourth identified break. This legislation - announced after the so-called Transfer Conference of April-May and enforced from July 1934 - made debt repurchases extremely difficult because of the complete monopoly of the Reichsbank over foreign exchange operations. As shown in Table 1, foreign debt repatriations had grown in volume over time since their start in 1931, peaking at over a billion Reichsmarks in 1933. After the policy tightening of 1934, however, they fell sharply and were kept under strict control for the rest of the decade.

As a result, there was enormous increase in the spread between German securities traded in Berlin and abroad, which could not be arbitraged away through debt repatriations. At the same time, for those who could engage in the practice, the arbitrage profits stemming from debt repatriations were higher than ever. This is clearly reflected in the price premium of foreign exchange that could be used for debt repatriations over standard foreign exchange, which grew massively after May 1934 and peaked in August 1934, before the market was suppressed (Table 2).

We are also able to pick up two further tightenings of exchange controls. The first took place in May-September $1937,{ }^{63}$ while the second is connected to the announcement and implementation of the foreign exchange law in November-December $1938^{64}$.

The last break we pick up is not an episode of financial repression or an event directly connected to Germany's foreign debt. Its importance for the probability of repayment of foreign debt holders, however, is difficult to dispute. This is the outbreak of World War II, represented by the Molotov-Ribbentrop pact and the German invasion of Poland on

\footnotetext{
${ }^{63}$ More precisely: on May 27, see Deutsches Reichsgesetzblatt, Jahrgang 1937, Teil I, Nr. 65, p. 600-601; and on September 16, see Deutsches Reichsgesetzblatt, Jahrgang 1937, Teil I, Nr. 105, p. 1018-19.

${ }^{64}$ November 8: Anträge auf Zuteilung von Devisen. December 12: Bekanntmachung des Gesetzes über die Devisenbewirtschaftung. Source: Deutsches Reichsgesetzblatt Jahrgang 1938, Teil I, Nr. 211, p. 1733-48.
} 
September 1st, 1939.

A remarkable aspect of our results is that we find consistent break dates for both London and New York, despite the different treatment creditors of the two countries received from Germany. This was generally more favorable for British creditors (Eichengreen and Portes, 1988a,b), mainly because the British government and the Corporation of Foreign Bondholders were active and successful in their lobbying on behalf of British investors (Auld, 1934). The US government, instead, had a generally laissez-faire attitude, and the American equivalent of the Corporation - the Foreign Bondholders Protective Council - was a recently-created institution (founded in 1933), as opposed to an experienced British counterpart active since 1868.

An example of differential treatment closely related to our structural break in 1934 is the Anglo-German Transfer Agreement of July 1934. With this, Germany reprised the service of the Dawes and Young loans held by British investors in full, while only offering partial payments to other creditors (Corporation of Foreign Bondholders, 1934). Yet, we identify a break in both new York and London. Restrictions on secondary market trading, instead, applied equally to all classes of creditors, leading us to conclude that these, rather than simply a change in the service of the loans, were the main driver of the downward revision of the price of German bonds both in London and New York.

Our results are also notable for what we do not find. The service of German foreign debt was modified - usually downwards - a number of times. However, we detect no breaks in correspondence to such events. In particular, the Law on Payments Abroad of May 1933, which marked the start of Germany's soon-to-be-complete default on its foreign debt, is not associated with a break in our analysis. Although the moratorium on foreign payments implemented in May 1933 did not initially affect the Dawes bonds and touched only the amortization of the Young bonds (Toniolo, 2005, pages 153-57), one would expect such an event to affect the expected probability of repayment for all foreign investors. ${ }^{65}$ Moreover, the Young and Dawes bonds were also directly impacted by the events of May 1933, given that the German government unilaterally revoked the Gold Clause, which meant that the Dawes and Young bonds started being serviced in nominal rather than in the original gold value basis.

This finding can be easily rationalized through the lenses of our model: price $P_{x}$ will not be affected by a reduction in the nominal value of the promised repayment if $\phi_{c}$ is low enough such that the price already incorporates the loss. ${ }^{66}$

To sum up, the breaks we find correspond to either key historical events or episodes related specifically to Germany's foreign debt, usually accompanied by partial or total defaults or restructurings. The distinctive features of these latter episodes, compared to those for which

\footnotetext{
${ }^{65}$ Prices recovered from mid-1933 until January 1934, probably due to a group of countries (Netherlands, Switzerland and briefly the UK) offering to raise their import quota of German goods in return for investor protection (Clement, 2004). This would have obviously had a positive impact on German foreign currency reserves and thus on the servicing of its foreign debt.

${ }^{66}$ As an example: if outstanding debt is 100 and $\phi_{c}$ is such that available resources for repayment are 70 $\left(P_{x}=0.7\right)$, then if the debtor announces that it will only consider the face value of its debt to be 90 this will not move the price as available resources to creditors remain 70 while nominal debt is still 100.
} 
we do not find structural breaks, was the tightening of foreign exchange controls. In line with our model, the accumulated evidence and our reading of the history, we conclude that exchange controls, by limiting the access of Germans to secondary markets, closed the "backdoor" channel through which the effects of limited foreign debt services and increased default probability for foreign debt holders could be offset. In fact, in the face of a purely external default such as the one we observe, debt repatriation would have represented a natural way for creditors to dismiss unwanted assets and for German citizens to profit on their higher probability of repayment.

\section{Conclusion}

This paper has looked back in history for insights on debt crises and the effects of capital controls. It found that political economy elements, such as internal redistribution considerations due to elite capture, play a relevant economic role. More precisely, we have studied the large repatriations of foreign debt carried out by Germans throughout the 1930s, historically one of the largest episodes of its kind. Previous studies of the episode could not explain all relevant known aspects of the episode, both at the micro and macro level. We show that the main features of the repatriations can be explained through the lenses of modern macroeconomic theory, in particular with a model that merges the main intuitions of Broner, Martin, and Ventura (2010) - on the role of secondary markets in sovereign risk - and Bulow and Rogoff (1991) - on the sub-optimality of debt buybacks - and extends them to allow for elite capture.

We argue that, despite the scarcity of foreign reserves, debt repatriations were not suppressed altogether once authorities stepped in to curb capital flight because they allowed the pursuit of specific micro-objectives. In fact, key companies, influential individuals, and the Nazi Party itself profited from these operations in the form of large capital gains, hidden export subsidies, or reduction of private debt exposure. At the same time, their use as a systematic macro-tool was ruled out as it would have led to excessive debt repayments, capital flight, depletion of official reserves, and welfare losses for the German economy as a whole, and this was known to the authorities.

Our interpretation is supported by published and unpublished historical documents and archival sources, as well as quantitative analysis of weekly spreads of German bonds in New York, London and Berlin. The spread analysis, in particular, reveals that government interventions and other events which hampered the efficiency of secondary markets had sharply negative effects on the price of German bonds abroad, while their prices were unaffected at home. This finding offers support for a key role of secondary markets in historical as well as in recent debt crises, such as the European one of the 2010s (Broner, Erce, Martin, and Ventura, 2014).

Our research can be extended by further investigating the economic and political mechanisms that lead to the emergence of elites, as well as their feedback effect on the economy in the context of cross-border transactions. We have no reason to believe that the relevance of our findings and theoretical approach is limited to 1930s Germany: the mechanism we 
analyzed could be applied to other settings, particularly to countries prone to elite capture. This opens the way for further empirical investigations of similar episodes.

On the theoretical side, research stemming from the Lucas Paradox (Lucas, 1990) shows a link between the quality of institutions and capital flows, while the literature on relationshipbased capitalism points to a relation between capital controls and quality of institutions. Thus, closing the circle some important questions remain open: Do lower quality institutions rely more on capital controls? Do capital controls, in turn, have a feedback effect on institutions? How does this affect the direction, size and impact of cross-border capital flows beyond the direct effects of capital controls? 


\section{References}

Accominotti, O., and B. Eichengreen (2016): "The Mother of All Sudden Stops: Capital Flows and Reversals in Europe, 1919-1932," Economic History Review, 69(2), 469-492.

Aguiar, M., And M. Amador (2014): "Sovereign Debt," in Handbook of International Economics, ed. by G. Gopinath, E. Helpman, and K. Rogoff, vol. 4, chap. 11, pp. 647 687. Elsevier.

Ahmed, F. Z., And L. Alfaro (2017): "Market reactions to sovereign litigation," Capital Markets Law Journal, 12(2), 141-163.

Alfaro, L., S. Kalemli-Ozcan, and V. Volosovych (2007): "Capital Flows in a Globalized World: The Role of Policies and Institutions," in Capital Controls and Capital Flows in Emerging Economies: Policies, Practices, and Consequences, NBER Chapters, pp. 19-72. National Bureau of Economic Research, Inc.

Alfaro, L., and I. Vogel (2006): "Creditor Activism in Sovereign Debt: "Vulture" Tactics or Market Backbone," Harvard Business School Case, 706-057(Revised April 2018).

Auld, G. P. (1934): "The Dawes and Young Loans: Then and Now," Foreign Affairs, $13(1), 6-25$.

Bai, J., And P. Perron (1998): "Estimating and Testing Linear Models with Multiple Structural Changes," Econometrica, 66(1), 47-78.

- (2003): "Computation and analysis of multiple structural change models," Journal of Applied Econometrics, 18(1), 1-22.

BAI, J., And S.-J. WeI (2012): "When Is There a Strong Transfer Risk from the Sovereigns to the Corporates? Property Rights Gaps and CDS Spreads," NBER Working Papers, 18600 .

Balogh, T. (1938): "The National Economy of Germany," Economic Journal, 48(191), 461-497.

Beck, R., G. Georgiadis, And J. GräB (2016): "The geography of the great rebalancing in euro area bond markets during the sovereign debt crisis," Journal of Empirical Finance, 38(PA), 449-460.

Bonnel, A. T. (1940): German Control over International Economic Relations, 1930-1940. The University of Illinois Press.

Broner, F., T. Didier, A. Erce, and S. L. Schmukler (2013): "Gross Capital Flows: Dynamics and Crises," Journal of Monetary Economics, 60, 113-133. 
Broner, F., A. Erce, A. Martin, and J. Ventura (2014): "Sovereign debt markets in turbulent times: Creditor discrimination and crowding-out effects," Journal of Monetary Economics, 61, 114-142.

Broner, F., A. Martin, and J. Ventura (2008): "Enforcement Problems and Secondary Markets," Journal of the European Economic Association, 6(2-3), 683-694.

(2010): "Sovereign Risk and Secondary Markets," American Economic Review, $100(4), 1523-55$.

Brown, W. O., and R. C. K. Burdekin (2002): "German Debt Traded in London during World War II: A British Perspective on Hitler," Economica, 69, 655-669.

Brutti, F., And P. Sauré (2016): "Repatriation of Debt in the Euro Crisis," Journal of the European Economic Association, 14(1), 145-174.

Buchheit, L., C. Delong, G. Chabert, and J. Zettlemeyer (2019): "How to Restructure Sovereign Debt: Lessons from Four Decades," Working Paper Series Peterson Institute for International Economics, WP19-8.

Bulow, J., And K. Rogoff (1988): "The Buyback Boondoggle," Brookings Papers on Economic Activity, 2, 675-715.

(1991): "Sovereign Debt Repurchases: No Cure for Overhang," Quarterly Journal of Economics, 106(4), 1219-1235.

Bundesbank (1976): Deutsches Geld- und Bankwesen in Zahlen, 1876-1975. Knapp.

Cetorelli, N., and L. S. Goldberg (2006): "Risks in U.S. Bank International Exposures," Federal Reserve Bank of New York Staff Reports, 240.

Child, F. C. (1958): The Theory and Practice of Exchange Control in Germany. Martinius Nijhoff.

Chong, T. T. L. (1995): "Partial parameter consistency in a misspecified structural change model," Economics Letters, 49(4), 351-357.

Clamssens, S., I. Diwan, K. Froot, and P. Krugman (1991): "Market-based debt reduction: principles and prospects," World Bank Policy and Research Series, 16.

Clanessens, S., and G. Embrechts (2003): "Basel II, Sovereign Ratings and Transfer Risk: External versus Internal Ratings," SSRN Electronic Journal.

Clement, P. (2004): "The Touchstone of German credit: Nazi Germany and the service of the Dawes and Young Loans," Financial History Review, 11(1), 33-50.

Cohen, D., And T. Verdier (1995): "'Secret' Buy-backs of LDC Debt," Journal of International Economics, 39(3-4), 317-334. 
Corporation of Foreign Bondholders (1934): Annual Report of the Council. Council House.

Costinot, A., G. Lorenzoni, and I. Werning (2014): "A Theory of Capital Controls as Dynamic Terms-of-Trade Manipulation," Journal of Political Economy, 122(1), 77-128.

De Broeck, M., And H. James (2019): "Germany in the Interbellum: Camouflaging Sovereign Debt," in Debt and Entanglements Between the Wars, ed. by T. Sargent, G. Hall, M. Ellison, A. Scott, H. James, E. Dabla-Norris, M. De Broeck, N. End, M. Marinkov, and V. Gaspar, chap. 6. International Monetary Fund.

Della Corte, V., and S. Federico (2019): "Two tales of foreign investor outflows: Italy in 2011-2012 and 2018," Questioni di Economia e Finanza (Occasional Papers), Bank of Italy, Economic Research and International Relations Area, 535.

D'Erasmo, P., and E. G. Mendoza (2016): "Distributional Incentives in an Equilibrium Model of Domestic Sovereign Default," Journal of the European Economic Association, 14(1), 7-44.

Dooley, M. P. (1996): "A Survey of Academic Literature on Controls Over International Capital Transactions," IMF Staff Papers, 43, 639-687.

Durdu, C. B., E. G. Mendoza, and M. E. Terrones (2009): "Precautionary demand for foreign assets in Sudden Stop economies: An assessment of the New Mercantilism," Journal of Development Economics, 89(2), 194-209.

Eaton, J., M. Gersovitz, and J. E. Stiglitz (1986): "The Pure Theory of Country Risk," European Economic Review, 30(3), 481-513.

Eichengreen, B., and R. Portes (1988a): "Foreign Lending in the Interwar Years: the Bondholders' Perspective," University of California Berkely, Department of Economics Working Paper, 8886.

272.

(1988b): "Settling Defaults in the Era of Bond Finance," CEPR Discussion Papers, (1990a): "The Interwar Debt Crisis and Its Aftermath," The World Bank Research Observer, 5(1), 69-94. 2867.

EInZIG, P. (1934): Germany's Default: The Economics of Hitlerism. Macmillan and co. limited.

Ellis, H. S. (1940a): "Exchange Control, 1931-1939: from an Emergency Measure to a Totalitarian Institution," Quarterly Journal of Economics, 54(4), 1-158. 
(1940b): "The Past and Future of Exchange Control," Quarterly Journal of Economics, 54(4), 159-217.

— (1941): Exchange Control in Central Europe. Harvard University Press.

Emter, L., M. Schmitz, And M. TiRpák (2019): "Cross-border banking in the EU since the crisis: What is driving the great retrenchment?," Review of World Economics (Weltwirtschaftliches Archiv), 155(2), 287-326.

Erce, A. (2012): "Selective Sovereign Defaults," Federal Reserve of Dallas Working Paper, Globalization and Monetary Policy Institute, 127.

Erce, A., and J. Díaz-Cassou (2010): "Creditor discrimination during sovereign debt restructurings," Working Paper, Banco de España, 1027.

Erce, A., And E. Mallucci (2018): "Selective Sovereign Defaults," International Finance Discussion Papers, Board of Governors of the Federal Reserve System, 1239.

Ferguson, T., And P. Temin (2003): "Made in Germany: the German Currency Crisis of July 1931," Research in Economic History, 21, 1-53.

(2004): "Comment on "The German Twin Crisis of 1931"," Journal of Economic History, 64(3), 872-876.

Ferguson, T., And H.-J. Voth (2008): "Betting on Hitler - The Value of Political Connections in Nazi Germany," Quarterly Journal of Economics, 123(1), 101-137.

Fernández, A., M. W. Klein, A. Rebucci, M. Schindler, and M. Uribe (2016): "Capital Control Measures: A New Dataset," IMF Economic Review, 64(3), 548-574.

Froot, K. (1989): "Buybacks, Exit Bonds, and the Optimality of Debt and Liquidity Relief," International Economic Review, 30(1), 49-70.

Ghosh, A. R., J. D. Ostry, and C. G. Tsangarides (2017): "Shifting Motives: Explaining the Buildup in Official Reserves in Emerging Markets Since the 1980s," IMF Economic Review, 65(2), 308-364.

Ghosh, A. R., And M. S. Qureshi (2016): "What's In a Name? That Which We Call Capital Controls," IMF Working Papers, 16/25.

Global Financial Data (2020): http://www.globalfinancialdata.com/.

Grossman, H. I., And J. B. VAn Huyck (1988): "Sovereign Debt as a Contingent Claim: Excusable Default, Repudiation, and Reputation," American Economic Review, 78(5), 1088-1097.

Guembel, A., And O. Sussman (2009): "Sovereign Debt without Default Penalties," Review of Economic Studies, 76(4), 1297-1320. 
Guinnane, T. W. (2004): "Financial Vergangenheitsbewältigung: the 1953 London Debt Agreement," Economic Growth Center, Yale University, Discussion Paper, 880.

Hahn, H. J. (1989): "German Foreign Exchange Control - Rise and Demise," The International Lawyer, 23(4), 873-890.

Hayek, F. A. (1944): The Road to Serfdom. University of Chicago Press.

Heuser, H. K. (1934): "The German Method of Combined Debt Liquidation and Export Stimulation," Review of Economic Studies, 1(3), 210-217.

Hinnerich, B. T., And P. Pettersson-Lidbom (2014): "Democracy, Redistribution, and Political Participation: Evidence From Sweden 1919-1938," Econometrica, 82(3), 961-993.

Huber, K., V. Lindenthal, and F. Waldinger (2020): "Discrimination, Managers, and Firm Performance: Evidence from "Aryanizations" in Nazi Germany," mimeo.

Institut FÜR KonjunktURForschung (1933): Konjunkturstatistiches Handbuch. R. Hobbing.

(1936): Konjunkturstatistiches Handbuch. R. Hobbing.

James, H. (1985): The Reichsbank and Public Finance in Germany, 1924-1933: A Study of the Politics of Economics during the Great Depression. Fritz Knapp Verlag.

(2004): "Banks and Business Politics in Nazi Germany," in Business and Industry in Nazi Germany, ed. by F. R. Nicosia, and J. Huener. Berghahn Books.

- (2020): "Neoliberalism and its Interlocutors," Capitalism: A Journal of History and Economics, 1(2), 484-518.

Johnson, S., And T. MitTon (2003): "Cronyism and capital controls: evidence from Malaysia," Journal of Financial Economics, 67(2), 351-382.

Katona, G. M. (1934): "How Real Is the German Recovery?," Foreign Affairs, 13(1), $26-44$.

Kejriwal, M., P. Perron, and J. Zhou (2013): "Wald Tests for Detecting Multiple Structural Changes in Persistence," Econometric Theory, 29(2), 289-323.

Klein, M. W. (2012): "Capital Controls: Gates versus Walls," NBER Working Papers, 18526.

Klug, A. (1993): "The German Buybacks 1932-1939: A Cure for Overhang?," Princeton Studies in International Finance, 75. 
Kobrak, C. (2003): "The Foreign-Exchange Dimension of Corporate Control in the Third Reich: The Case of Schering AG," Contemporary European History, 12(1), 33-46.

Krugman, P. (1988): "Market-Based Debt-Reduction Schemes," NBER Working Papers, 2587.

Kuczynski, R. R. (1933): "Germany and Gold," The Annals of the American Academy of Political and Social Science, 165(1), 207-209.

Lee, J., And M. C. Strazicich (2003): "Minimum Lagrange Multiplier Unit Root Test with Two Structural Breaks," The Review of Economics and Statistics, 85(4), 1082-1089.

Lucas, Robert E, J. (1990): "Why Doesn't Capital Flow from Rich to Poor Countries?," American Economic Review, 80(2), 92-96.

Magud, N. E., C. M. Reinhart, and K. S. Rogoff (2018): "Capital Controls: Myth and Reality-A Portfolio Balance Approach," Annals of Economics and Finance, 19(1), $1-47$.

Panizza, U., F. Sturzenegger, and J. Zettelmeyer (2009): "The Economics and Law of Sovereign Debt and Default," Journal of Economic Literature, 47(3), 651-698.

Pasricha, G. (2020): "Estimated Policy Rules for Capital Controls," IMF Working Papers, 20.

Pitchford, R., and M. L. J. Wright (2012): "Holdouts in Sovereign Debt Restructuring: A Theory of Negotiation in a Weak Contractual Environment," Review of Economic Studies, 79(2), 812-837.

Poole, K. E. (1939): German Financial Policies 1932-1939. Harvard University Press.

Power, P. J. (1996): "Sovereign Debt: The Rise of the Secondary Market and its Implications for Future Restructurings," Fordham Law Review, 64(6), 2701-2772.

Rajan, R. G., And L. Zingales (1998): "Which Capitalism? Lessons Form The East Asian Crisis," Journal of Applied Corporate Finance, 11(3), 40-48.

Reinhart, C. M., and K. S. Rogoff (2004): "Serial Default and the Paradox of Richto-Poor Capital Flows," American Economic Review, 94(2), 53-58.

(2013): "Financial and Sovereign Debt Crises: Some Lessons Learned and those Forgotten," CEPR Discussion Paper Series, 9750.

(2014): "This Time is Different: A Panoramic View of Eight Centuries of Financial Crises," Annals of Economics and Finance, 15(2), 215-268.

Reinhart, C. M., and R. T. Smith (2002): "Temporary controls on capital inflows," Journal of International Economics, 57(2), 327-351. 
Ritschl, A. (2001): "Nazi Economic Imperialism and the Exploitation of the Small: Evidence from Germany's Secret Foreign Exchange Balances, 1938-1940," Economic History Review, 54(2), 324-345.

(2012): "The German Transfer Problem, 1920-1933: A Sovereign Debt Perspective," European Review of History: Revue Europeenne d'Histoire, 10, 943-964.

(2013): "Reparations, Deficits, and Debt Default: The Great Depression in Germany," in The Great Depression of the 1930s, ed. by N. Crafts, and P. Fearon, chap. 4, pp. 110-139. Oxford University Press.

(2019): "Financial Destruction: Confiscatory Taxation of Jewish Property and Income in Nazi Germany," LSE Economic History Working Papers, 297.

Ritschl, A., and S. Sarferaz (2014): "Currency vs. Banking in the Financial Crisis of 1931," International Economic Review, 55(2), 349-373.

Schacht, H. (1934): "German Trade and German Debts," Foreign Affairs, 13(1), 1-5.

Schnabel, I. (2004a): "The German Twin Crisis of 1931," Journal of Economic History, 64(3), 822-871.

— (2004b): "Reply to Thomas Ferguson and Peter Temin's "Comment on 'The German Twin Crisis of 1931'"," Journal of Economic History, 64(3), 877-878.

- (2009): "The Role of Liquidity and Implicit Guarantees in the German Twin Crisis of 1931," Journal of International Money and Finance, 28(1), 1-25.

Schuker, S. (1988): American Reparations to Germany, 1924-1933. Princeton University Press.

Schularick, M., And T. M. Steger (2008): "The Lucas Paradox and the quality of institutions: then and now," Free University Berlin, School of Business 83 Economics Discussion Papers, 2008/3.

Schumacher, J., C. Trebesch, and H. Enderlein (2018): "Sovereign defaults in court," European Central Bank Working Paper Series, 2135.

Schwarz, H. P. (1982): Die Wiederstellung des Deutschen Kredits: das Lodoner Schuldenabkommen. Belser Verlag.

Tahoun, A. (2014): "The role of stock ownership by US members of Congress on the market for political favors," Journal of Financial Economics, 111(1), 86-110.

Temin, P. (2008): "The German Crisis of 1931: Evidence and Tradition," Cliometrica, 2, $5-17$. 
The Annalist (1930-1940): The Annalist: A Journal of Finance, Commerce and Economics, vol. 35-56 of January 1930 - October 1940. The New York Times Company.

The Financial Times (1929-1932): The Financial Times $\& 3$ Weekly Supplements, December 1929 - December 1932.

Toniolo, G. (2005): Central Bank Cooperation at the Bank for International Settlements, 1930-73. Cambridge University Press.

U.S. Department of State Bulletin (1952a): "U.S. Bondholders Urged to Communicate with Committee for German Corporate Bonds, Press Release 884 Dated Nov. 21, 1952," Vol. 27, 947-948.

_ (1952b): "Validation of German Dollar Bonds," Vol. 27, 608-614.

Weidemaier, M. (2014): "Sovereign Immunity and Sovereign Debt," University of Illinois Law Review, 2014(1).

Wright, M. L. (2006): "Private capital flows, capital controls, and default risk," Journal of International Economics, 69(1), 120-149. 


\section{Appendix}

\section{A Model}

\section{A.1 An increase in $\omega_{s}$ always reduces $X^{*}$}

The marginal effect of $\omega_{s}$ on the FOC (eq. 11) is (assuming $\alpha>0.5$ and $\sigma_{a}$ ):

$$
\overbrace{(2 \alpha-1)}^{\text {positive }} \overbrace{(-\underbrace{\frac{\partial\left(\frac{X}{P_{x}}\right)}{\partial X}}_{\geq 1}+\underbrace{\left.\frac{\partial R_{x}}{\partial X}\right)}_{\geq-1} \underbrace{-\gamma}_{\text {negative }})}^{\text {negative }}<0
$$

Thus an increase in $\omega_{s}$ always reduces $X^{*}$.

\section{A.2 The effect of an increase in $\alpha$ and its interaction with $\omega_{s}$}

Under the same assumptions as above we study the marginal effect of an increase in $\alpha$ on the FOC:

$$
\left(2 \omega_{s}-1\right) \overbrace{(-\underbrace{\left(\frac{\partial\left(\frac{X}{P_{x}}\right)}{\partial X}\right.}_{\geq 1}+\underbrace{\left.\frac{\partial R_{x}}{\partial X}\right)}_{\geq-1} \underbrace{-\gamma}_{\text {negative }})}^{\text {negative }}+\overbrace{\frac{\partial\left(\frac{X}{P_{x}}\right)}{\partial X}-1}^{\text {positive }}
$$

The sign of eq. (13) will depend crucially on the sign of $\left(2 \omega_{s}-1\right)$.

- When $\omega_{s} \leq 0.5$, the condition is always positive and an increase in $\alpha$ increases $X^{*}$, unless the non-negativity condition on $X=0$ is binding.

For the case when $\omega_{s}>0.5$, it is easier to rewrite eq. (13) and to substitute in the actual derivative of $R_{x}$ :

$$
\overbrace{\underbrace{\left(2-2 \omega_{s}\right)}_{\geq 0} \underbrace{\frac{\partial\left(\frac{X}{P_{x}}\right)}{\partial X}}_{\geq 1}}^{\geq 0}+\overbrace{\underbrace{\left(2 \omega_{s}-1\right)}_{>0 \& \leq 1} \underbrace{\left(-\left(-\beta \phi_{c}\right)-\gamma\right)}_{>-1 \&<1}-1}^{<0}
$$

- When $\omega_{s}=1$, the first additive term goes to zero and only the additional marginal costs are left. In this case, an increase in $\alpha$ always decreases $X^{*}$. Remember that when $\alpha=0.5$ then $X^{*}=0$, so $X^{*}=0$ holds for any value of $\alpha$.

- When $0.5<\omega_{s}<1$, the sign of the effect of an increase in $\alpha$ on $X^{*}$ will depend on the balance between the additional marginal benefits and costs, therefore on the actual 
values of the structural parameters. One can see that lower additional marginal costs are associated with higher values of $\beta$ and $\phi_{c}$ (the additional domestic repayments are not much larger than what foreigners would get) and lower values of $\gamma$ (less income forfeited through the public good). The additional marginal gains, on the other hand, are higher with higher values of $\beta$ and $\phi_{c}$.

\section{A.3 The role of $\beta$ and $\gamma$}

The marginal effects of both $\beta$ and $\gamma$ have been already discussed in the main text. In Figure 8 we show the joint effect on $X^{*}$ of $\beta$ and $\gamma$, for representative given values of $\phi_{c}, \alpha$, and $\omega_{s}$, and fixing $D_{0}=100$.

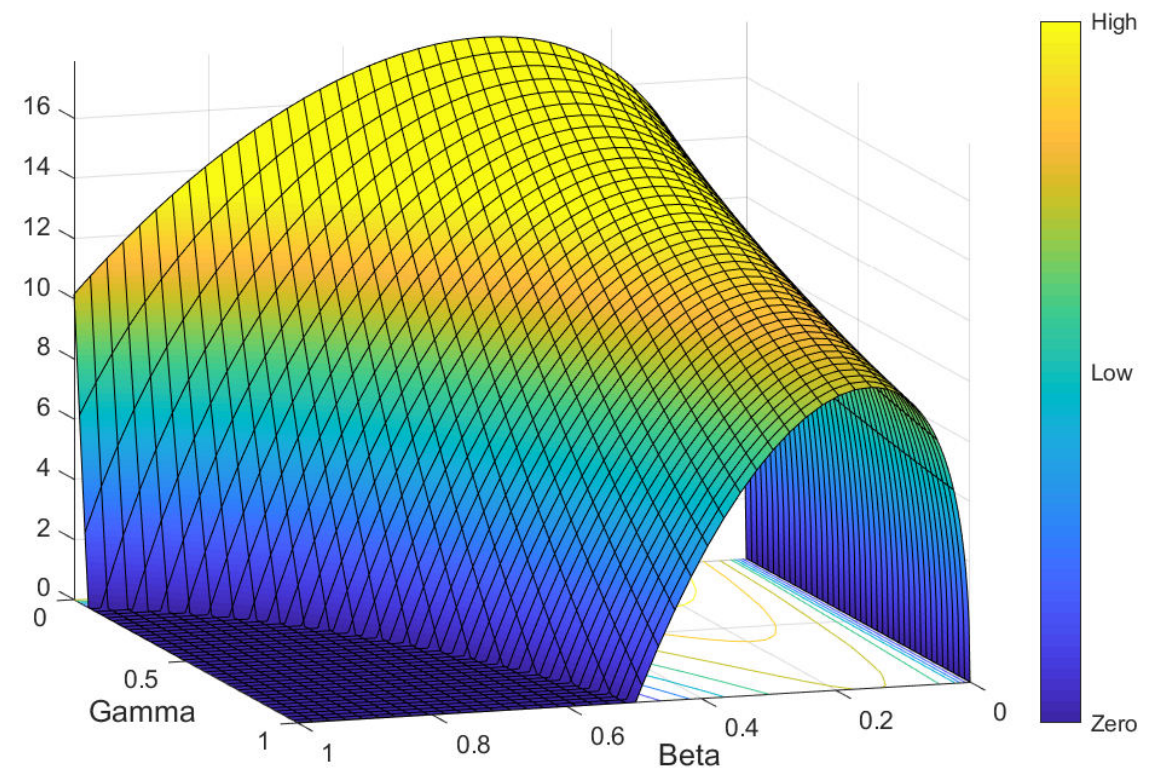

Figure 8: Optimal $X^{*}$ on the vertical axis. $\phi_{c}$ was fixed at $0.8, \omega_{s}=0.1$, and $\alpha=0.7$.

\section{A.4 Alternative enforcement technology $\sigma$}

Here we consider two alternative specifications ${ }^{67}$ for $\sigma$ :

$$
\begin{aligned}
\sigma_{b}\left[X \mid Y_{p}, \phi_{c}\right] & =\beta\left(\phi_{c} Y_{p}-\max \left\{0, X-\left(1-\phi_{c}\right) Y_{p}\right\}\right) \\
\sigma_{c}\left[X \mid Y_{p}, \phi_{c}\right] & =\beta \max \left\{0, \phi_{c} Y_{p}-X\right\}
\end{aligned}
$$

Function $\sigma_{b}$ (15a) covers the case where $X$ originates first from domestic resources shielded by capital controls (which amount to $\left.\left(1-\phi_{c}\right) Y_{p}\right)$ and only when, and if, these

\footnotetext{
${ }^{67}$ The function could be linear or nonlinear: Bulow and Rogoff (1991) provide more necessary conditions for the nonlinear case.. We do not include an intercept for tractability, which would represent debt enforcement independent of capital controls e.g. military occupation.
} 
are exhausted by $X$, funds are taken from resources available to creditors through $\sigma$. We can view this case as one more favorable to creditors relative to the reference one because, for low levels of $X$, some resources normally already defaulted upon will be transferred to creditors without a corresponding decline in expected repayments. Only when enough $X$ has been used for repatriations, given $\phi_{c}$, will resources available to creditors begin to decline, thus reducing $\sigma_{b}$. This implies no correlation between $X$ and $\sigma_{b}$ for low levels of $X$ and a negative correlation for higher levels.

In contrast to the previous case, $\sigma_{c}(15 \mathrm{~b})$ can be viewed as one more favorable to debtors, where $X$ is financed first with resources that would have otherwise been seized by creditors, implying a negative correlation between $X$ and $\sigma_{b}$ for low levels of $X$ and no correlation for higher values. ${ }^{68}$

We now show that the main results of the model presented in section 5 hold also under a different enforcement technology $\sigma$. The two graphs in Figure 9 are constructed in exactly the same way as Figure 3, except that $\sigma_{b}$ and $\sigma_{c}$ (equations 15a and 15b) are substituted in each case for $\sigma_{a}$ (equation 7). Under all three scenarios, when $\alpha=0.5$ then $X^{*}=0$, and $X^{*}>0$ only if $\alpha>0.5$. As argued in section $5, \sigma_{b}$ is the technology that, among the three proposed, discourages repatriations the most. In fact, when the boxplot in Figure 3 (in the main text) is compared with the boxplot in Figure 9a it can be noted that, as expected, the distribution of $X^{*}$ has more mass towards zero in the case of $\sigma_{b}$, but nonetheless it allows for positive $X^{*}$ under some parameter combinations when $\alpha>0.5$. On the other hand, the model under $\sigma_{c}$ - the technology that most encourages repatriations - has less mass of $X^{*}$ on the zero outcome, but also in this case when $\alpha=0.5$, then $X^{*}=0$.

\section{A.5 Comparison with related models}

Comparing our model to the closest literature allows us to highlight some interesting features and novelties of our approach. We generalize BR's main result over another dimension of policy making by means of simple microfoundations, thus separating individual and collective interests. The main economic force at play is still one that leads to $X^{*}=0$, and for the same reason as in BR. However, in our case, that force can be countered by an unequal government preference for the welfare of different groups of citizens, which pushes the government to adopt a policy $X^{*}>0$ because detrimental effects are borne by all citizens (through equation 8 and decreased public good provision), while the benefits are only enjoyed by the preferred group. ${ }^{69}$

As previously discussed, direct relation with the results of BR is evident when considering

\footnotetext{
${ }^{68}$ This is not the only way to see that this case is favored by debtors: in the context of private commercial debt traded domestically (i.e. creditors and debtors share the same jurisdiction, so $\beta=1$ representing perfect enforcement of contracts) this corresponds to corporate debt buybacks, where an issuer buys back its own debt. Buybacks are therefore always beneficial because, lacking better investment opportunities, in exchange for less than a dollar, they allow retiring a dollar's worth of collateral that could be seized in the event of default. See Bulow and Rogoff (1988) for details and limitations of this case.

${ }^{69} \mathrm{BR}$ note that by relaxing some conditions in their model they can numerically obtain a positive optimal $X$. However, they find that this holds only for a range of structural parameters values they deem unrealistic.
} 


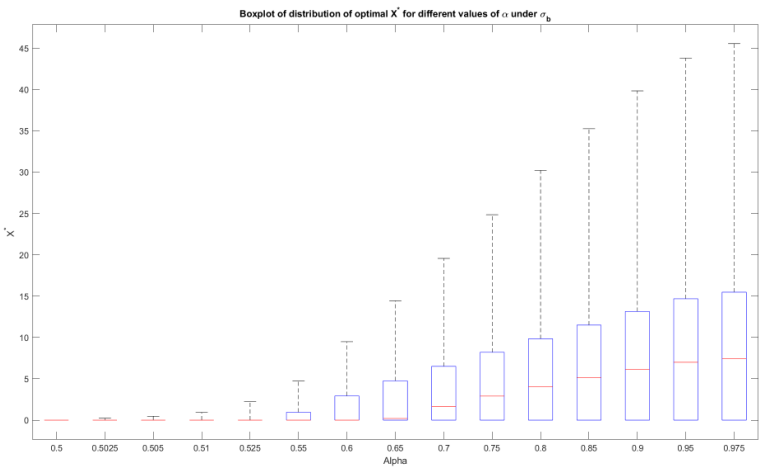

(a) $\sigma_{b}$

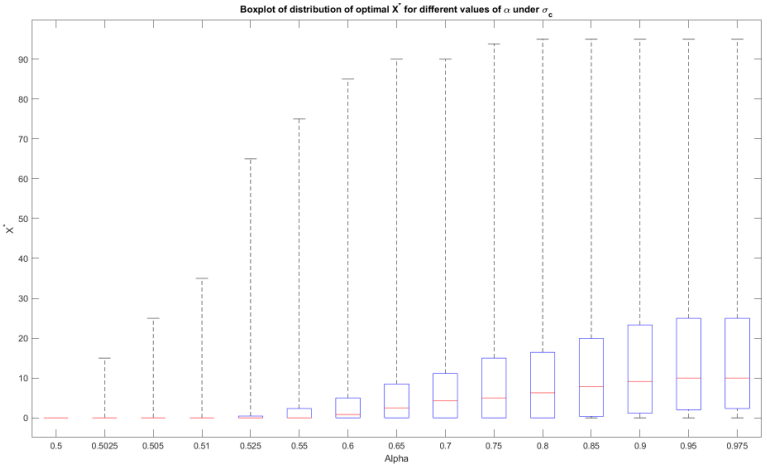

(b) $\sigma_{c}$

Figure 9: Boxplot of the distribution of $X^{*}$ for different values of $\alpha$, under $\sigma_{b}$ and $\sigma_{c}$. For each value of $\alpha$, the model is solved for all combinations of 15 values for each of the parameters $\beta, \gamma, \omega_{s}, \phi_{c}$, for a total of 50625 grid points for each value of $\alpha$. The 15 values are: $(0.025,0.05,0.10,0.125,0.15,0.20,0.25,0.35,0.45,0.55,0.65,0.75,0.85,0.95,0.975)$. Horizontal axis not to scale.

a higher $\omega_{s}$ (the supporters group size), everything else equal: the extreme case of $\omega_{s}=1$ (all citizens are supporters) is exactly the case of BR, where collective and group interests match perfectly and therefore $X^{*}=0$. If an individual within the group could deviate from the government decision, then she would make capital gains at the expense of all others: the government solves exactly this coordination problem. In general, when $X^{*}>0$, the higher the number of citizens allowed to engage in repatriations, the lower $X^{*}$ becomes, until it quickly reaches zero again; note that $\omega_{s}$ need not necessarily reach 1 for $X^{*}=0$. This happens because, as $\omega_{s}$ increases, the collective detrimental effects of repatriations in the form of higher domestic repayments in $\rho$ are gradually internalized by more supporters and capital gains cannot compensate for this (eq. 11). Conversely, decreasing $\omega_{s}$ when $X^{*}>0$ will lead to a higher $X^{*}$. Note that these outcomes in the spirit of BR can be observed on the supply side of $X$, i.e. the government's choice of $X$ that maximizes the social welfare function.

A comparison with BMV must start by highlighting one key difference: in the language of our model, BMV assume that the government can control $\beta$ and nothing else, and that trade on secondary markets is purely driven by unregulated private incentives. ${ }^{70}$ Similarly to BMV, in our model agents also have private incentives to repatriate but, as in BR, the government controls $X$, thereby limiting private demand for it.

In BMV, when debt is in foreign hands the government will of course choose $\beta=0$ to strategically default on foreigners, the socially preferable outcome. However, smoothly functioning secondary markets allow for a full circumvention of that policy as citizens can access any level of $X$ they can afford to repatriate debt for their own profit. In equilibrium all debt is therefore repatriated (i.e. $\left.D_{x}=0\right)^{71}$ and no strategic default is possible when

\footnotetext{
${ }^{70}$ To fully compare our model to BMV one must assume $\omega_{s}=1$ and no government spending (1) (or $\gamma=0$ ).

${ }^{71}$ To see this, note that when $\beta=0$, eq.(5) becomes $P_{x}=X / D_{0}$, which then simplifies in (3) to get $D_{x}=0$.
} 
$\phi_{c}=1$. In contrast with BMV, we allow $R_{x}$ to be non-zero and its relation with $X$ defined in $\sigma$ : this permits partial repatriations $\left(D_{x}>0\right)$.

It is in this comparison with BMV that the crucial role played by secondary markets stands out the most. In fact, given $\beta$ and $\phi_{c}$, in our model the values of the different $\sigma$ are generally not the same. Since different specifications of $\sigma$ represent alternative implementations of capital controls, this shows that how secondary markets are impaired matters and it should be explicitly modeled, separately from other sources of debtor-creditor interaction.

Other papers, notably Krugman (1988) and Froot (1989), also reach the conclusion that sovereign buybacks can be socially beneficial under specific conditions. While noting that their frameworks are very different from ours, they depart most notably by assuming the specific case of $\beta=1$, an assumption closer to a case of corporate buyback (see footnote 68). This highlights the importance of studying more general frameworks for debt repatriations, especially when it concerns the debtor-creditor interaction as in function $\sigma$.

An issue featured prominently in most models mentioned in this section is that of debt overhang. We do not address it directly, but overhang can be included by adding two small extensions to the model. First, an alternative use for the government endowment not used for repatriations, representing the efficient domestic allocation of resources potentially affected by foreign debt. Second, the resources that creditors can seize $\left(Y_{p}\right)$ should depend on this allocation of resources. However, since our model generalizes BR by using similar model mechanics of international markets, and because the channel of debt overhang reduction increases resource allocation efficiency, we believe it would lead to a higher or at most unchanged $X^{*}$, which would only strengthen our result.

\section{B Empirical Methodology}

The dynamic optimization procedure of Bai and Perron $(1998,2003)$ finds the structural breaks dates $\left(T_{1}, \ldots, T_{m}\right)$ of a partial structural change model such that:

$$
\left(\hat{T}_{1}, \ldots, \hat{T}_{m}\right)=\operatorname{argmin}_{T_{1}, \ldots, T_{m}} \sum_{j=1}^{m+1} \sum_{t=T_{j-1}+1}^{T_{j}}\left[y_{t}-\hat{\alpha}_{j\left[T_{j}\right]}-\hat{\rho}_{j\left[T_{j}\right]} y_{t-1}-\hat{\beta}_{\left[T_{j}\right]} z_{t}\right]
$$

where $y_{t}$ is our series on interest, either one of the reconstructed series of the spread or the price level of the Dawes and Young bonds traded in New York and London; $z_{t}$ is the exogenous control for local market performance (as explained in the main text), and the hat denotes sample estimates. There are $m+1$ regimes $j=1, \ldots, m+1$ (with $T_{0}=0$ and $\left.T_{m+1}=T\right)$, where $m$ is the number of breaks and the subscript $\left[T_{j}\right]$ represents the dependence of parameter estimates on the date of the breaks.

BMV propose a variation of their model (Example 9, page 1544) that allows for what can be interpreted as debt repatriations under impaired secondary markets. However, also in that case all debt is repatriated. 


\section{B.1 Practical implementation}

We implement this algorithm using a Matlab "translation" of the original GAUSS code of Bai and Perron (2003) downloaded from the website of Yohei Yamamoto, Hitotsubashi University. We subsequently modified the code (see comments in the file brcode.m for more details). We set the trimming value $h$ as suggested by Bai and Perron (2003), except in some cases concerning Young bonds, where we augment the value of $h$ by $10-15 \%$. This is done because our series for Young bonds in London has 36 observation less at the beginning of the sample than the London Dawes bonds, and the series in New York has 24 observations less than the New York Dawes bonds series. This not only means that the two Young series start in a period of higher volatility but also that the beginning of the sample is very close to the reconstructed subsample. We do not believe that augmenting $h$, however minimally, could lead to a "false" break date being selected in that first part of the sample, as the result of Chong (1995) applies in this case.

The confidence intervals are calculated allowing for the moment matrix of the data to vary across the identified regimes. For each of the bonds the reported confidence intervals are those estimated from the model with most breaks among the reported ones. For a break that is present both in a model with $M$ and $M+1$ breaks its confidence interval is in practice not affected, if so only marginally, when estimated from the model with $M+1$ breaks.

\section{B.2 Full structural breaks results}

[Intentionally left blank. Table on next page.] 


\begin{tabular}{|c|c|c|c|c|c|c|c|c|}
\hline \multirow{2}{*}{ Series } & \multicolumn{7}{|c|}{ Break } & \multirow[b]{2}{*}{ Other } \\
\hline & 1 & 2 & 3 & 4 & 5 & 6 & 7 & \\
\hline \multirow{2}{*}{ LSE Dawes M1 } & 26 Sept 1931 & 11 June 1932 & 4 March 1933 & 10 Mar 1934 & & 31 Dec 1938 & 2 Sep 1939 & \\
\hline & 29/8/31-28/11/31 & $9 / 4 / 32-18 / 6 / 32$ & $25 / 2 / 33-1 / 4 / 33$ & $24 / 2 / 34-7 / 4 / 34$ & & $30 / 7 / 38-7 / 1 / 39$ & $2 / 9 / 39-2 / 9 / 39$ & \\
\hline \multirow{2}{*}{ LSE Dawes M2 } & 11 Apr 1931 & 11 June 1932 & 4 March 1933 & 10 Mar 1934 & & 31 Dec 1938 & 2 Sep 1939 & \\
\hline & $21 / 06 / 30-25 / 07 / 31$ & $26 / 03 / 32-25 / 06 / 32$ & $25 / 2 / 33-1 / 4 / 33$ & $24 / 2 / 34-21 / 4 / 34$ & & $27 / 8 / 38-7 / 1 / 39$ & 2/9/39-2/9/39 & \\
\hline \multirow{2}{*}{ LSE Dawes M3 } & 1 Aug 1931 & 11 June 1932 & 4 March 1933 & 10 Mar 1934 & & 31 Dec 1938 & 2 Sep 1939 & \\
\hline & $27 / 6 / 31-26 / 9 / 31$ & $16 / 04 / 32-18 / 06 / 32$ & $25 / 2 / 33-1 / 4 / 33$ & $24 / 2 / 34-14 / 4 / 34$ & & $13 / 8 / 38-7 / 1 / 39$ & $2 / 9 / 39-2 / 9 / 39$ & \\
\hline \multirow{2}{*}{ LSE Dawes M4 } & 26 Sep 1931 & 11 June 1932 & 4 March 1933 & 10 Mar 1934 & & 31 Dec 1938 & 2 Sep 1939 & \\
\hline & $27 / 6 / 31-28 / 11 / 31$ & $2 / 4 / 32-18 / 6 / 32$ & $25 / 2 / 33-1 / 4 / 33$ & $24 / 2 / 34-14 / 4 / 34$ & & $13 / 8 / 38-7 / 1 / 39$ & $2 / 9 / 39-2 / 9 / 39$ & \\
\hline \multirow{2}{*}{ LSE Young M1 } & 10 Oct 1931 & 11 June 1932 & 11 Feb 1933 & 3 Mar 1934 & & 31 Dec 1938 & 2 Sep 1939 & \\
\hline & $1 / 8 / 31-26 / 12 / 31$ & $28 / 5 / 32-11 / 6 / 32$ & $11 / 2 / 33-18 / 02 / 33$ & $17 / 2 / 34-31 / 3 / 34$ & & $9 / 7 / 38-7 / 1 / 39$ & $26 / 8 / 39-2 / 9 / 39$ & \\
\hline \multirow{2}{*}{ LSE Young M2 } & & 11 June 1932 & 11 Feb 1933 & 10 Mar 1934 & 14 Aug 1937 & 26 Nov 1938 & 2 Sep 1939 & 23 Mar 1935 \\
\hline & & $28 / 5 / 32-11 / 06 / 32$ & $11 / 02 / 33-18 / 02 / 33$ & $3 / 2 / 34-7 / 4 / 34$ & $23 / 1 / 37-2 / 10 / 37$ & 19/11/38-14/1/39 & $12 / 8 / 39-2 / 9 / 39$ & $24 / 11 / 34-20 / 07 / 35$ \\
\hline \multirow{2}{*}{ LSE Young M3 } & 26 Sep 1931 & 11 June 1932 & 11 Feb 1933 & 3 Mar 1934 & & 31 Dec 1938 & 2 Sep 1939 & \\
\hline & $27 / 06 / 31-14 / 11 / 31$ & $04 / 06 / 32-18 / 06 / 32$ & $11 / 2 / 33-18 / 2 / 33$ & $17 / 2 / 34-21 / 4 / 34$ & & $20 / 8 / 38-7 / 1 / 39$ & $26 / 8 / 39-2 / 9 / 39$ & \\
\hline \multirow{2}{*}{ LSE Young M4 } & 10 Oct 1931 & 11 June 1932 & 11 Feb 1933 & 3 Mar 1934 & & 31 Dec 1938 & 2 Sep 1939 & \\
\hline & $05 / 09 / 31-07 / 11 / 31$ & $04 / 06 / 32-11 / 06 / 32$ & $11 / 2 / 33-18 / 2 / 33$ & $17 / 2 / 34-14 / 4 / 34$ & & $13 / 8 / 38-7 / 1 / 39$ & $26 / 8 / 39-2 / 9 / 39$ & \\
\hline \multirow{2}{*}{ NYSE Dawes M1 } & 11 Jul 1931 & 11 June 1932 & 11 Feb 1933 & 5 May 1934 & 4 Sep 1937 & 1 Oct 1938 & 26 Aug 1939 & \\
\hline & $18 / 04 / 31-18 / 07 / 31$ & $28 / 05 / 32-11 / 06 / 32$ & $4 / 02 / 33-4 / 03 / 33$ & $28 / 4 / 34-2 / 6 / 34$ & $30 / 1 / 37-4 / 9 / 37$ & $24 / 9 / 38-18 / 2 / 39$ & 4/3/39-9/9/39 & \\
\hline \multirow{2}{*}{ NYSE Dawes M2 } & 5 Sep 1931 & 11 June 1932 & 11 Feb 1933 & 5 May 1934 & 4 Sep 1937 & 1 Oct 1938 & 26 Aug 1939 & \\
\hline & $11 / 07 / 31-26 / 09 / 31$ & $14 / 05 / 32-25 / 06 / 32$ & $4 / 02 / 33-4 / 03 / 33$ & $28 / 4 / 34-9 / 6 / 34$ & $23 / 1 / 37-4 / 9 / 37$ & 24/09/38-11/2/39 & 18/3/39-9/9/39 & \\
\hline \multirow{2}{*}{ NYSE Dawes M3 } & 11 July 1931 & 11 June 1932 & 11 Feb 1933 & 5 May 1934 & 4 Sep 1937 & 1 Oct 1938 & 26 Aug 1939* & \\
\hline & $18 / 04 / 31-18 / 07 / 31$ & $28 / 05 / 32-18 / 06 / 32$ & $04 / 02 / 33-04 / 03 / 33$ & $28 / 4 / 34-9 / 6 / 34$ & $16 / 1 / 37-4 / 9 / 37$ & $1 / 10 / 38-11 / 2 / 39$ & & \\
\hline \multirow{2}{*}{ NYSE Dawes M4 } & 3 Oct 1931 & 11 June 1932 & 11 Feb 1933 & 5 May 1934 & 4 Sep 1937 & 1 Oct 1938 & 26 Aug 1939 & \\
\hline & $12 / 9 / 31-17 / 10 / 31$ & $21 / 05 / 32-18 / 06 / 32$ & $4 / 2 / 33-4 / 3 / 33$ & $28 / 4 / 34-2 / 6 / 34$ & $23 / 1 / 37-4 / 9 / 37$ & $24 / 9 / 38-18 / 2 / 39$ & $4 / 3 / 39-9 / 9 / 39$ & \\
\hline \multirow{2}{*}{ NYSE Young M1 } & 4 Jul 1931 & 11 June 1932 & 11 Feb 1933 & 3 March 1934 & 4 Sep 1937 & 26 Nov 1938 & 26 Aug 1939 & \\
\hline & $23 / 5 / 31-18 / 7 / 31$ & $28 / 5 / 32-11 / 6 / 32$ & $4 / 2 / 33-25 / 2 / 33$ & $24 / 2 / 34-28 / 4 / 34$ & $21 / 11 / 36-4 / 9 / 37$ & $5 / 11 / 38-21 / 1 / 39$ & $22 / 7 / 39-16 / 9 / 39$ & \\
\hline \multirow{2}{*}{ NYSE Young M2 } & & 11 June 1932 & 11 Feb 1933 & 3 March 1934 & 17 Apr 1937 & 26 Nov 1938 & 26 Aug 1939 & 9 Nov 1935 \\
\hline & & $28 / 5 / 32-18 / 6 / 32$ & $11 / 2 / 33-18 / 2 / 33$ & $24 / 2 / 34-21 / 4 / 34$ & $20 / 2 / 37-17 / 7 / 37$ & $5 / 11 / 38-31 / 12 / 38$ & $5 / 8 / 39-23 / 9 / 39$ & $12 / 10 / 35-4 / 1 / 36$ \\
\hline \multirow{2}{*}{ NYSE Young M3 } & 4 Jul 1931 & 11 June 1932 & 11 Feb 1933 & 3 March 1934 & 4 Sep 1937 & 26 Nov 1938 & 26 Aug 1939 & \\
\hline & $2 / 5 / 31-11 / 7 / 31$ & $4 / 6 / 32-18 / 6 / 32$ & $11 / 2 / 33-25 / 2 / 33$ & $24 / 2 / 34-28 / 4 / 34$ & $14 / 11 / 36-11 / 9 / 37$ & $5 / 11 / 38-14 / 1 / 39$ & 29/7/39-16/9/39 & \\
\hline \multirow{2}{*}{ NYSE Young M4 } & 10 Oct 1931 & 11 June 1932 & 11 Feb 1933 & 3 March 1934 & 4 Sep 1937 & 26 Nov 1938 & 26 Aug 1939* & \\
\hline & $12 / 9 / 31-17 / 10 / 31$ & $4 / 6 / 32-11 / 6 / 32$ & $11 / 2 / 33-25 / 2 / 33$ & $24 / 2 / 34-5 / 5 / 34$ & $24 / 10 / 36-11 / 9 / 37$ & $19 / 11 / 38-13 / 5 / 39$ & & \\
\hline
\end{tabular}

Table 4: Breaks and corresponding confidence intervals for the various spread series of German bonds between Berlin, London and New York. $\mathrm{LSE}=$ London Stock Exchange, NYSE= New York Stock Exchange. *only with highest number of breaks supported by the SupF test. 


\section{B.3 Robusteness checks}

Our results are robust to allowing for different forms of heteroskedasticity across regimes of the moment matrix of the regressors and of the variance of the residuals, as available in the code and documented in Bai and Perron (2003). We also use a different control variable for New York, specifically a subindex of 40 industrial bonds (included in the dataset). Another robustness check consists of running the analysis on the price level of the bonds instead of the spread. Moreover, for all models we repeat the analysis with the dependent variable $y$ as the spread series (the results of which are reported in the main text), the foreign (NY or London) price level, or the log-level of the foreign price, always controlling for the level of the stock index.

\section{B.4 Reconstructed spread series}

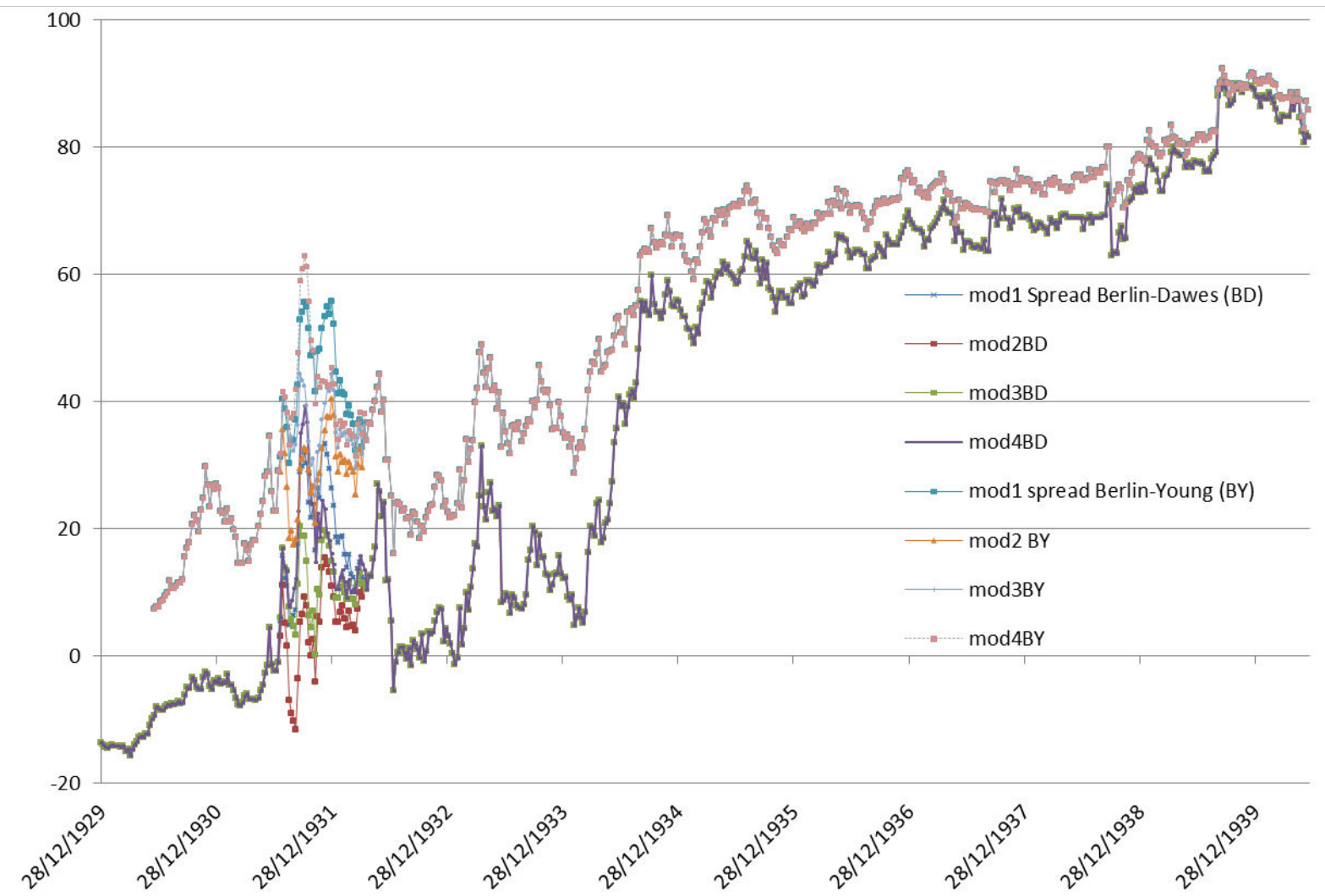

Figure 10: Four reconstructed spreads series of Dawes and Young bond prices traded in New York with respect to mortgage bonds prices traded in Berlin. Weekly frequency. See main text for sources.

The Berlin Stock Exchange was closed between July 1931 and April 1932. We reconstruct the missing values under different scenarios, all but one involving an eight-week slump in prices correlated to the dynamics of the US stock market (data from Global Financial Data). The scenarios differ in the timing of the slump (ranging from mid-July to August until 
October-November 1931), whereas one consists in a linear interpolation for the whole missing subsample. For the three scenarios where we reconstruct a crash we use an underlying trend for the whole subsample, upon which we "add" the crash. The trend is constructed from the League of Nations Statistical Yearbook 1932-33, where we find monthly yields for a sample of representative German fixed interest securities for the period when the Berlin Stock exchange was closed. We take the implied monthly growth rate of these representative securities and linearly interpolate them to get weekly figures.

We then use these reconstructed series for the Berlin mortgage bonds to get four different spreads series for the Dawes and Young bonds respectively, in NY and in London, for a total of sixteen spread series, all available in the data files. Figure 10 shows the eight reconstructed spread series for New York: with respect to Young and Dawes bonds alike, the series obviously overlap for the whole sample, except for the reconstructed subsample. Similarly, data for the London series can be found in the Matlab data files.

\section{Further historical background}

\section{C.1 The composition of German debt in 1931}

Data collected from archival sources provides further insights into the context in which the German debt repatriations took place. In particular, we have a snapshot of the nature and composition of German foreign commercial debts at the end of November 1931, in the early stages of repatriations. As mentioned in the text, the USA was Germany's principal creditor and industry the principal debtor. Although America's lending to Germany has been often highlighted as exceptional and at least partially politically motivated - Schuker (1988) called it "American reparations to Germany" - the USA was the principal lender of the 1920s for a good number of countries. Accominotti and Eichengreen (2016) have recently shown that around 66\% of all European bond issues between 1924 and 1928 took place in New York. England, the Netherlands, Switzerland, France and the Bank for International Settlements also had significant holdings (Table 5).

The geographical distribution of this short-term debt was somewhat different from the long term one, with the USA playing a less prominent role and the debt being more evenly distributed across the other principal creditors. The distribution of short term debt amongst debtor sectors was also different, with the industrial sector playing a slightly smaller role and the public sector's share being higher than that for overall debt (Table 6).

German commercial foreign debt was issued in a variety of currencies, but the US Dollar

was the principal currency of denomination (Table 7). Around $50 \%$ of the debt was issued in US currency, $12 \%$ in British Pounds, 11\% in Reichsmarks, 10\% in Swiss Francs and 9\% in Dutch Guilders. 


\begin{tabular}{lr}
\hline Creditor country & Debt share \\
\hline USA & $41.72 \%$ \\
Netherlands & $16.96 \%$ \\
Switzerland & $12.96 \%$ \\
UK & $12.94 \%$ \\
France & $4.79 \%$ \\
Bank for International Settlements & $3.49 \%$ \\
Italy & $0.69 \%$ \\
\hline
\end{tabular}

(a) by creditor country

\begin{tabular}{lr}
\hline Debtor sector & Debt share \\
\hline Industry & $61.68 \%$ \\
Public bodies & $16.38 \%$ \\
Banks & $15.35 \%$ \\
Reichsbank and Golddiskontbank & $3.67 \%$ \\
Private citizens & $2.41 \%$ \\
Insurance companies & $0.40 \%$ \\
School, churches etc. & $0.11 \%$ \\
\hline
\end{tabular}

(b) by debtor sector

Table 5: Total German foreign commercial debt, November 1931.

Source: Bank of England Archive OV34/69: Die Auslandsverschuldung Deutschlands nach dem Stande von 30. November 1931.

\begin{tabular}{lr}
\hline Creditor country & Debt share \\
\hline USA & $27.02 \%$ \\
Netherlands & $17.26 \%$ \\
Switzerland & $16.30 \%$ \\
UK & $14.04 \%$ \\
Bank for International Settlements & $7.52 \%$ \\
France & $5.41 \%$ \\
Italy & $0.76 \%$ \\
Other countries & $11.69 \%$ \\
\hline
\end{tabular}

(a) by creditor country

\begin{tabular}{lr}
\hline Debtor sector & Debt share \\
\hline Industry & $53.00 \%$ \\
Public bodies & $25.97 \%$ \\
Banks & $8.34 \%$ \\
Reichsbank and Golddiskontbank & $7.52 \%$ \\
Private citizens & $4.58 \%$ \\
Insurance companies & $0.47 \%$ \\
School, churches etc. & $0.12 \%$ \\
& \\
\hline
\end{tabular}

(b) by debtor sector

Table 6: German foreign short-term commercial debt, November 1931.

Source: Bank of England Archive OV34/69: Die Auslandsverschuldung Deutschlands nach dem Stande von 30. November 1931.

\begin{tabular}{lr}
\hline Currency & Debt share \\
\hline US Dollar & $50.0 \%$ \\
Pound Sterling & $11.8 \%$ \\
Reichsmark & $10.7 \%$ \\
Swiss Franc & $9.7 \%$ \\
Dutch Guilder & $9.2 \%$ \\
French Franc & $3.6 \%$ \\
Other currencies & $4.9 \%$ \\
\hline
\end{tabular}

Table 7: German foreign commercial debt by currency of issue, November 1931.

Source: Bank of England Archive OV34/69: Die Auslandsverschuldung Deutschlands nach dem Stande von 30. November 1931. 


\section{C.2 Controls and repatriations}

\section{C.2.1 The exchange control system}

Explaining the origin and impact of the German exchange control system was the main concern of many contemporary authors, and some successive ones as well, writing about Germany's foreign economic policy in the 1930s. We summarize this literature here, as a reference for readers interested in a better understanding of the broader context of the repatriations.

Writing in the post-war period, Child (1958) saw the exchange control system as a highly sophisticated trade policy tool, in line with views prevalent in the 1930s expressed, for example, by Heuser (1934), Einzig (1934) and Katona (1934). Child argued that the German authorities used the system to manipulate the size, direction and terms of trade in Germany's favor, by exploiting the county's monopolistic/monopsonistic position in certain markets, especially in South-Eastern Europe and Latin America.

Heuser (1934) and Child (1958) attributed Germany's reliance on overt and disguised export subsidies and other manipulations of trade to the inapplicability of policies normally employed to stimulate exports and reduce imports. The additional export system was, according to Heuser, one of the few options left to Germany to increase exports and thus maintain foreign debt service.

Devaluation was ruled out, at least initially, due to the large size of the foreign-currency denominated debt, which would have increased dramatically in real value. Moreover, forfeiting the gold anchor might have led to further capital flight, as well as to an increase in the import prices of essential raw materials and to general inflationary pressures bearing unpleasant memories of the hyperinflation of less than a decade earlier (Heuser, 1934; Ellis, 1940a). The alternative to devaluation and export subsidies was additional deflationary policies. Imposing these on an already depressed economy, however, might have caused violent social unrest and additional capital flight.

However, in a modern reassessment of Nazi Germany's trade policy, Ritschl (2001) has ruled out a successful attempt by the German authorities to significantly shape trade flows before WWII, at least in European markets. Matters changed with military occupation, after which the exploitation of occupied countries became enormous. This substantially weakens the trade tool argument for the exchange control system.

Another contemporary, Ellis (1940a), concurred with the trade tool interpretation, but restricted its validity to a limited time frame, arguing that, after 1933, the perpetuation of exchange controls ceased to have an economic rationale and was, instead, based on political objectives of the National Socialist regime. Specifically, he argued that, as the National Socialist government's Aktive Konjunkturpolitik (active business cycle policy) gained importance after 1934, exchange controls were an essential tool for guaranteeing the coexistence of expansionary monetary and fiscal policies with a fixed exchange rate. In other words, they became an effective financial repression tool aimed at channeling resources to government financing. At the same time, they were one of the many facets of the NSDAP's totalitarian control of trade, investment and the economy in general. 


\section{C.2.2 The conversion of foreign bonds}

As discussed in Section 4.2, repatriated foreign currency bonds could be converted into domestic Reichsmarks bonds. ${ }^{72}$ The principal governmental actor involved in this operation was the Reichsbank subsidiary Golddiskontbank. The Bank physically took custody of the repatriated foreign bonds from the bondholders and issued new Reichsmarks-denominated bonds. An example of this can be seen in Figure 11, which features both the original and reissued bond. This particular bond was Austrian - issued by the Styrian Water Power and Electricity company - and was converted in December 1939. In fact, after the Anschluss of 1938, Austrian foreign bonds were eligible for conversion by the German Golddiskontbank. In this case, the bond, originally issued in 1929, for a face value of $\$ 50$ was converted into a 132 Reichsmarks bond, implying an exchange rate of 2.64 Reichsmarks per dollar, slightly above the official 2.5 exchange rate. The coupon of the bond was reduced from the original $6 \%$ to $4.5 \%$ in line with the mandated interest rate within Germany.

Interestingly, the initiative for converting the bonds could come from both the holders of the repatriated bonds and the original issuers. The former had several reasons for engaging in conversions. First, this would ensure the regular and full servicing of the bonds, albeit with a reduced coupon and in domestic rather than foreign currency. Second, from June 1934, converted bonds could be sold on the stock market, opening the way to immediate and large arbitrage profits. The final motivation for the conversion of bonds was the increasing scrutiny under which foreign currency holdings of Germans came as the Nazi government tightened its grip on the German economy and society. Conversion offered the possibility of turning foreign currency assets into domestic ones at advantageous conditions.

Bond issuers also had reasons to propose and incentivize the conversion of bonds. The principal one, already outlined in Section 4.2, is that the blanket foreign default imposed by the sovereign might not have served the needs and desires of individual bond issuers. Reputational considerations and the desire to preserve ties with foreign suppliers, clients and other counterparts spurred some debtors to encourage the repatriation of their bonds by issuing public offers of conversion. Conversion also facilitated the buyback of the bonds by the company at a later stage. This was especially relevant if the issuer could not carry out repatriations on its own because of foreign exchange scarcity. Finally, a larger debt service in Reichsmarks may have been preferable to a limited one in foreign currency. Once again, foreign exchange scarcity was the reason, given that currency had competing and potentially preferable uses compared to debt service, for example the acquisition of production inputs.

Figure 12 provides an example of a conversion offer by the original issuer, in this case Dortmund municipal utilities. The offer was issued on March 26, 1934 and was binding until April 15. The bond to be converted was issued in 1928 with a $6.5 \%$ coupon and had a 20 year maturity. The exchange rate offered was decisively more generous than the one above, at 3 Reichsmarks per dollar, against a 2.54 official exchange rate. The coupon was also slightly higher, $4.75 \%$, as this conversion preceded the March 1935 law-mandated change of all coupons to $4.5 \%$.

\footnotetext{
${ }^{72}$ We thank Josefin Meyer and Hans-Georg Glasemann for useful comments and discussions on this topic.
} 


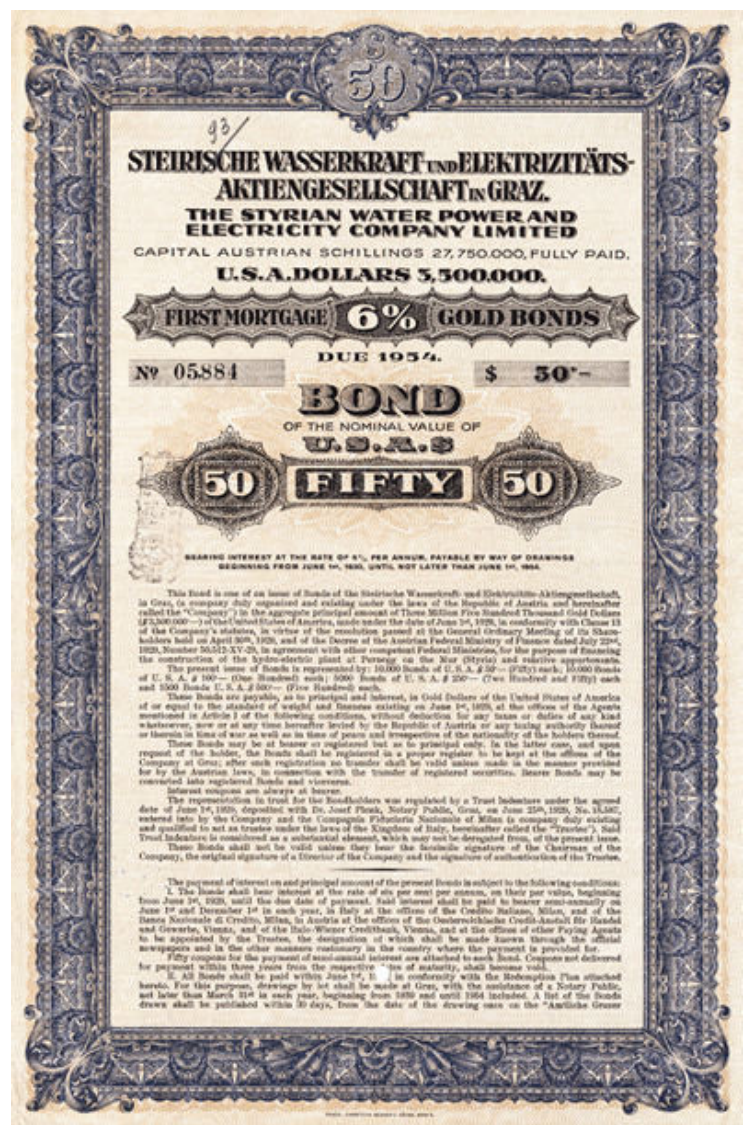

(a) Original

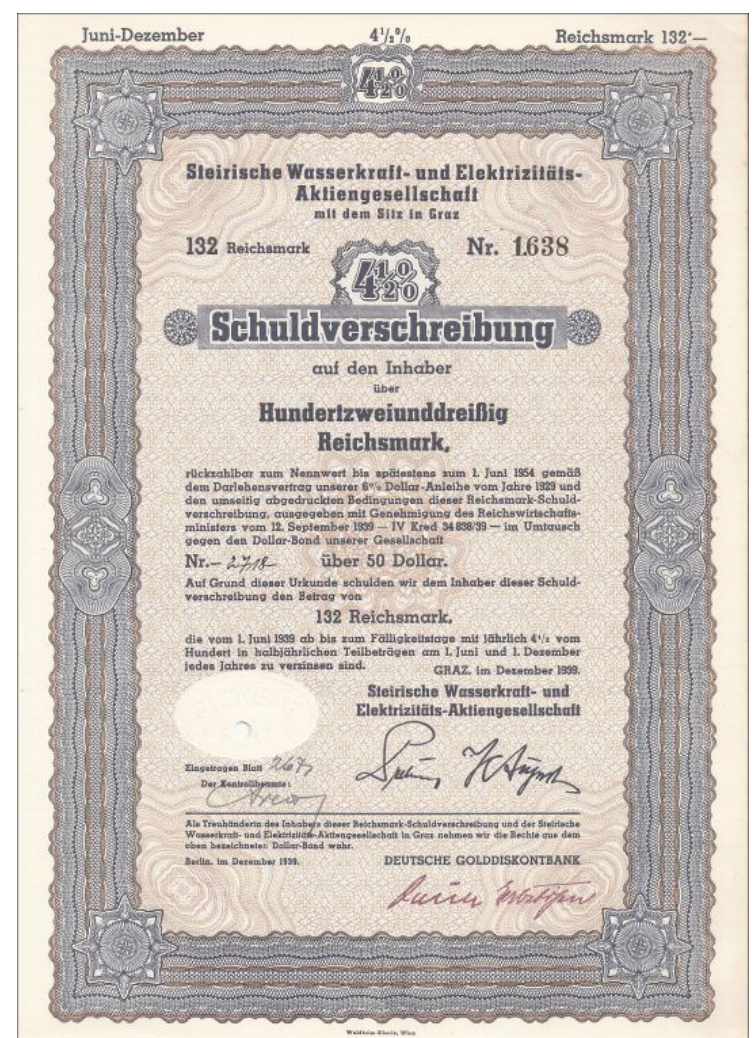

(b) Converted

Figure 11: An original gold dollar bond and the corresponding converted Reichsmarks bond.

This Austrian gold dollar bond was issued in 1929 and due in 1954. The original $\$ 50$ face value in the original issue (left panel) was converted into 132 Reichsmarks (right) by the German Golddiskontbank in 1939. The coupon was lowered from 6 to 4.5\%. Source: Hans-Georg Glasemann, http://www.nonvaleurs.de/

\section{C.2.3 Scrip and blocked accounts operations}

Blocked accounts constituted the service of German foreign debts in Reichsmarks - at first only of short-term Standstill debts, but after 1933 also of long-term debts - which was blocked from being transferred abroad. In essence, they were arrears of German foreign debt, serviced in domestic rather than foreign currency. Foreign importers could purchase German goods using their holdings of these accounts. A discount of between 30 and $60 \%$, depending on the origin of the blocked account, was applied to the face value of the accounts in these transactions (Ellis, 1941).

Scrip was also arrears. More precisely, it was German currency with no legal tender, which was used from June 1933 to pay $50 \%$ of the debt service (70\% from December of the same year) on non-Standstill debts. Scrip could be purchased by those wishing to import German goods in foreign financial centers (often at substantial discount). After the export transaction, the scrip was converted into Reichsmarks by the Golddiskontbank 


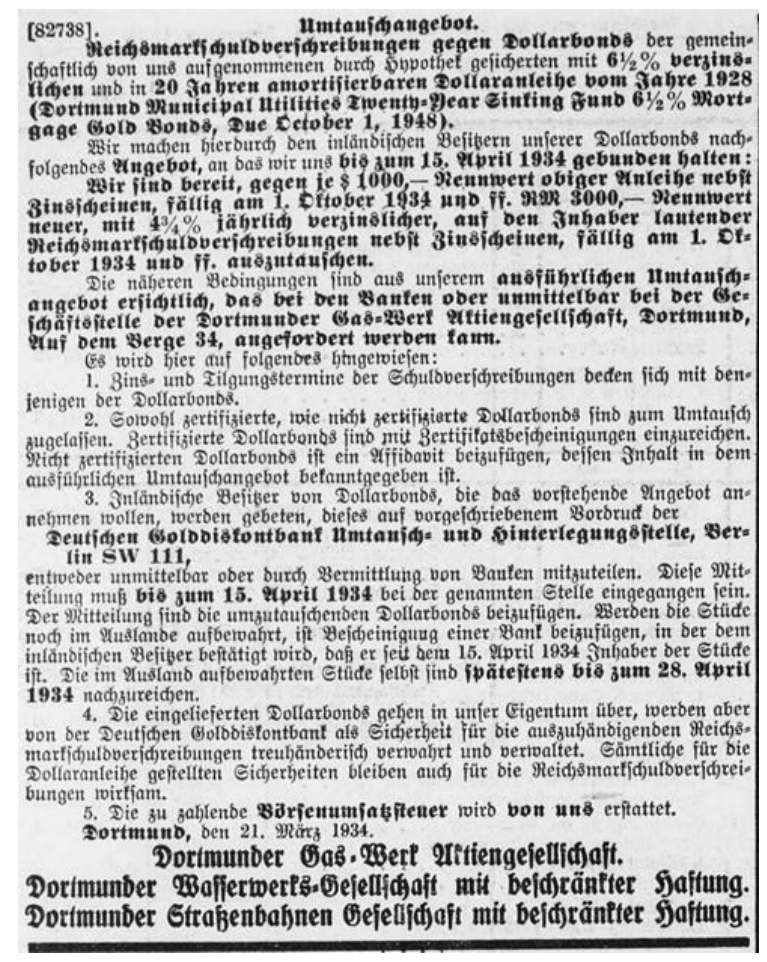

Figure 12: Example of a conversion offer (Umtauschangebot) by the original issuer.

This offer was put out by the Dortmund municipal utilities company to German holders of a 1928 issue due in 1948 of gold dollar bonds to convert them into Reichsmarks bonds at the Golddiskontbank. Source: Deutscher Reichsanzeiger und Preußischer Staatsanzeiger, Vierte Beilage, No. 72, March 26, 1934.

at an exchange rate that allowed the central bank to share in the profits of the operation.

As discussed in Section 4.2, scrip and blocked account operations were fairly similar to each other and involved the transfer of these depreciated Reichsmarks from foreign creditors to Germans exporters, who could then turn these into regular Reichsmarks for a profit. Initially, foreign importers would procure these assets to be used in partial payment (up to $60 \%$ ) of German goods on financial markets. From June 1933, this passage was no longer necessary, as the repatriation of these assets would take place through the mediation of the Konversionskasse and the Golddiskontbank. The economic mechanisms underpinning the operations, however, did not change. As stated by Heuser (1934, page 213): "The fact that the foreign creditor prefers an immediate realisation of his claim, even at the risk of a loss, rather than the postponement of it to an uncertain future, is again at the basis of the new scheme. The main difference between the old and the new method lies in the fact that the export price reduction is now effected internally, independently of the foreign importer, for whom it is no longer possible or necessary to acquire depreciated marks in order to obtain German goods at a lower price."

Heuser provided a schematic representation of this newer system, which illustrates its complex working and the various players, both public and private, involved. We reproduce this scheme in Figure 13 for the reader interested in the details of the repatriations carried 
out in this more unusual and intricate manner. The specific discounts applied to the various transactions capture the situation in the first half of 1934, after the Law on Payments Abroad (approved in May 1933) and successive modifications to the level of debt service were passed, but before the complete moratorium of July 1934 was enforced.

The German debtor would pay the debt service in Reichsmarks to the Konversionskasse. $30 \%$ of this service would be transferred by the Konversionskasse to the foreign creditor in foreign exchange provided by the Reichsbank, provided that this did not exceed $4 \%$ of the principal. The rest of the service would be paid in scrip, which, as mentioned, was German currency with no legal tender. The creditor could turn the scrip over to a bank in its country of origin for $67 \%$ of its face value, leading to a total $77 \%$ debt service. The bank would then sell the scrip to the Golddiskontbank at $69 \%$ of its face value. At the same time, a German exporter could obtain authorization - after "proving" that its production costs exceed world prices - to use part of the foreign exchange from its export transactions to purchase scrip from the Golddiskontbank at 30\% discount. The scrip obtained could then be turned into Reichsmarks at face value at the Konversionskasse leading to a profit that would make up for the supposed sale below cost. The rest of the foreign exchange, the share depended on the estimate of the loss incurred by the exporter in the sale abroad, would be transferred to the Reichsbank.

Transactions with blocked accounts operated within this system as well. The difference was simply that the owner of blocked accounts could liquidate its outstanding balances at the Konversionskasse at discounts that depended on the original claim generating the blocked account. Blocked accounts could represent Registered Marks, Credit Marks, or other forms of blocked Marks. The owner of the liquidated blocked accounts would receive either scrip or claim certificates, which would then enter the additional export system.

\section{C.2.4 Colonel Francis Norris and Siegfried Wreszynski}

Norris and Wreszynski were a British subject and a citizen of Danzig, respectively. Norris had been a member of the Inter-allied Commission of Control in Germany, a body set up by the Treaty of Versailles. The two partners enjoyed some moments of tabloid fame in 1933-35 due to their lavish Park-lane millionaires lifestyle in London and Paris, as well as for the curiosity surrounding the nature of their fortunes. Sometimes as trustees, other times as debt factors, they would intermediate the unfreezing of blocked accounts and the repatriation of German bonds for large holders, such as banks, large companies (e.g. Unilever), and the Vatican. Accusations of fraud made by some of their clients in England, France, and the Netherlands are difficult to assess, as they could be part of larger political power plays to dismantle their operation. In any case, their demise was as quick as their rise. Norris was indicted in France in May 1934 and expelled from the country in 1935, yet never arrested. Wreszynski was arrested in Amsterdam in 1938 for small-time frauds, only three years after a diamond-packed wedding to Norris' former wife and herself a business partner. After his release four years later he went into hiding, as he was a Jew in occupied Netherlands. After the war, he was sentenced for frauds, committed during his hiding, against families of captured Dutch resistance members. 


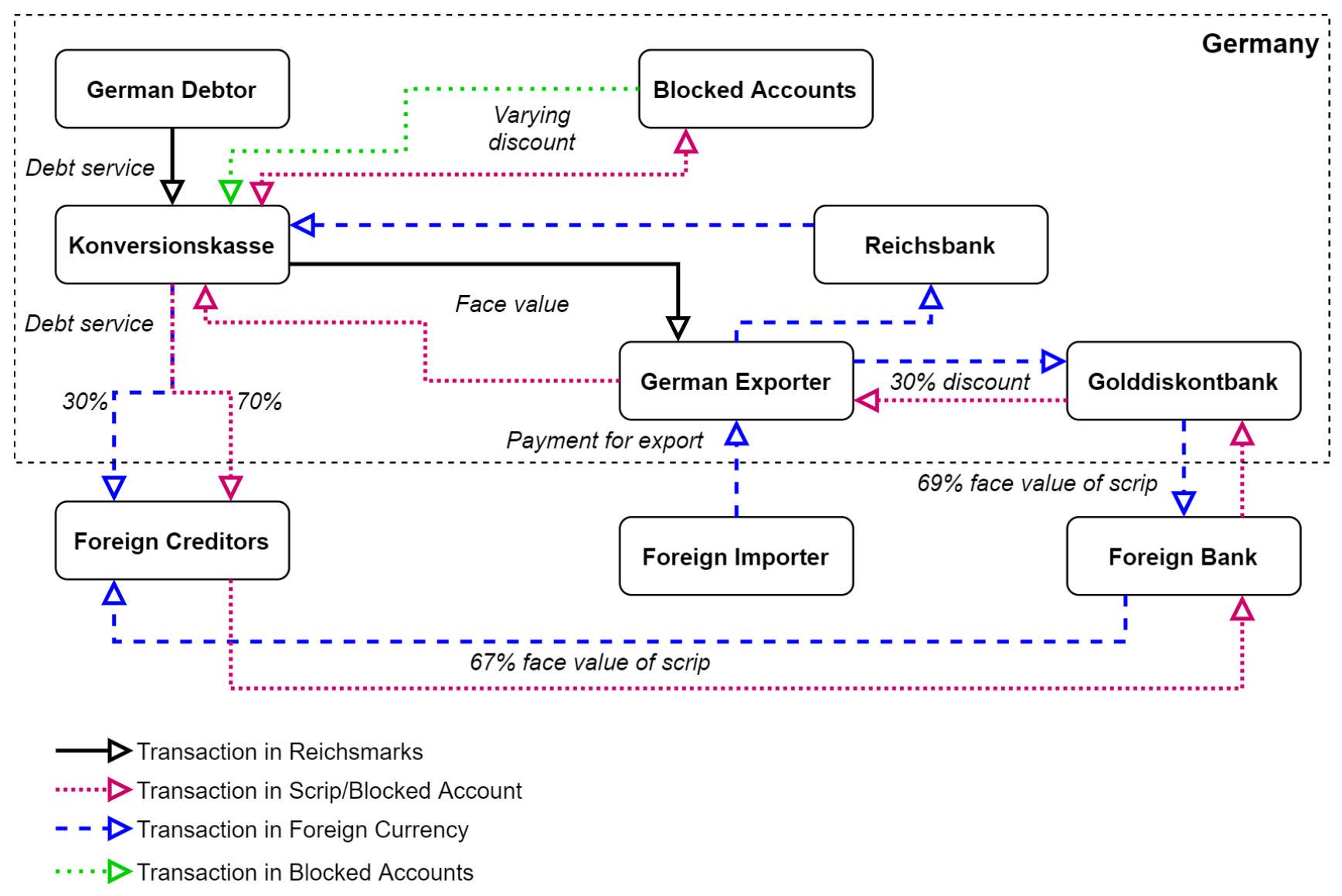

Figure 13: The repatriation scheme involving scrip and blocked accounts.

The diagram refers to the period after May 1933, and the various discounts and debt service levels to the period between December 1933 and July 1934. Source: adapted by the authors from Heuser (1934). 